\title{
Õpetamistegevused ja õpilaste tekstimõistmine üleminekul esimesest kooliastmest teise astmesse
}

\author{
Krista Uibu ${ }^{\text {a1 }}$, Mairi Männamaa ${ }^{\text {bc }}$ \\ a Tartu Ülikooli haridusteaduste instituut \\ b Tallinna Ülikooli psühholoogia instituut \\ c SA Tartu Ülikooli Kliinikumi lastekliinik
}

\begin{abstract}
Annotatsioon
Tekstimõistmine on seotud verbaalse võimekusega, info kodeerimise ja integreerimisega ning sõnatähenduse tundmisega. Õpetajad kasutavad erinevaid õpetamistegevusi, et toetada õpilaste keelelist, sh tekstimõistmise arengut. Uurimuse eesmärk oli välja selgitada õpetajate õpetamistegevuste (mehaanilise õpetamise, arusaamise arendamise, teadmiste rakendamise) mõju õpilaste tekstimõistmisele üleminekul esimesest kooliastmest teise astmesse. Töös hinnati klassiõpetajate $(N=48)$ õpetamistegevusi ja nende muutust 3. ja 4. klassis ning õpetamistegevuste seoseid õpilaste $(N=609)$ tekstimõistmise ja verbaalse võimekuse muutusega 4. ja 5. klassis. Analüüsimisel kasutati nii rühma- kui ka indiviidikeskseid meetodeid. Õpetamistegevuste eelistuste alusel eristusid õpetajate profiilirühmad ning tekstimõistmise komponentide ja verbaalse võimekuse alusel õpilaste rühmad. Selgus, et tekstimõistmise testi tulemused olid stabiilselt halvemad õpilastel, kes olid verbaalselt vähem võimekad ja kelle õpetajad eelistasid kõiki õpetamistegevusi vähe. Samas esines sarnaseid õpetamistegevuste kombinatsioone erinevates õpilaste profiilirühmades. Arendamaks õpilaste tekstimõistmisoskust, on oluline, et õpetajad arvestaksid õpilaste verbaalse võimekusega ja kasutaksid õpetamistegevusi kooskõlas laste keelelise arenguga.
\end{abstract}

Võtmesõnad: tekstimõistmine, verbaalne võimekus, õpetamistegevused, pikiuurimus

1 Haridusteaduste instituut, sotsiaal- ja haridusteaduskond, Tartu Ülikool, Salme 1a, 50103 Tartu; krista.uibu@ut.ee 


\section{Sissejuhatus}

Põhikoolis omandavad õpilased elementaarse lugemisoskuse ja tekstimõistmisoskuse. Tekstimõistmine on funktsionaalse lugemisoskuse üks näitajaid. Hea lugemisoskus pole tähtis mitte üksnes keeleliste osaoskuste kontekstis, vaid see on aluseks akadeemilisele edukusele kõikides õppeainetes (Cain \& Oakhill, 2007). Samas on lapsi, kes ei saa rahuldavast või heast elementaarsest lugemisoskusest hoolimata tekstist hästi aru (Lervåg \& Aukrust, 2010). Majanduskoostöö ja Arengu Organisatsiooni (OECD) õpilaste rahvusvahelise hindamisprogrammi Programme for International Student Assessment (PISA) 2009. aasta tulemuste järgi on Eesti õpilased OECD riikide seas loetu mõistmises kümnendal kohal, Euroopas osalenud riikide seas kõrgel viiendal kohal (Tire, Puksand, Henno, \& Lepmann, 2010). Eesti põhikooli õpilased sooritavad esimese ja teise kooliastme lõpus ka emakeele tasemetöö. 2012. aastal oli tekstimõistmise, sh sõnavaraülesande lahendusprotsent suhteliselt kõrge: esimeses kooliastmes 78,5\%, teises 85,6\% (Hennoste, 2012).

Kuigi lapsed saavad häid tulemusi nii rahvusvahelistes kui ka Eesti uurimustes, leidub esimeses, teises ja kolmandas kooliastmes õpilasi, kellel esineb raskusi eakohaste tekstide mõistmisega (Henno, Tire, Lepmann, Reiska, \& Ehala, 2007; Soodla \& Kikas, 2010; Tire et al., 2010). Nõrgema tekstimõistmisoskusega laste seas võib olla erineva vaimse võimekusega lapsi (Cain \& Oakhill, 2006), vähem võimekate õpilaste hulgas on tekstimõistmise raskustega lapsi rohkem (Reynolds \& Turek, 2012). Peale võimete taseme on leitud erinevusi ka poiste ja tüdrukute tekstimõistmises, enamasti tüdrukute kasuks (Logan \& Johnston, 2010; Tire et al., 2010). Erinevuste põhjusi on otsitud poiste ja tüdrukute võimete ning lugemisoskuse varieeruvuses, lugemisstrateegiates, õppimisstiilis ja motivatsioonis (Logan \& Johnston, 2010).

Oma osa õpilaste lugemisoskuse kujunemisel on õpetajate tegevustel ja strateegiatel (Foorman et al., 2006; Perry, Donohue, \& Weinstein, 2007). Kuna eri kooliastmetes on lugemisel mõnevõrra erinev eesmärk - algkoolis omandatakse põhisõnavara ja elementaarne lugemisoskus, keskastmes tekstimõistmise oskus ja suur hulk aineteadmisi -, tuleks lugemisoskuse arendamiseks kasutada erinevaid õpetamistegevusi (Gleason \& Ratner, 2009). Nende tegevuste mõju hindamine võib aga osutuda keeruliseks, sest lugemisoskus baseerub õpilaste kognitiivsetel ja metalingvistilistel oskustel (Chomsky, 1964). Siinse uurimuse eesmärk oli välja selgitada muutused õpilaste tekstimõistmises ja verbaalses võimekuses ning analüüsida õpetajate õpetamistegevuste mõju nendele muutustele. 


\section{Tekstimõistmist mõjutavad tegurid}

Puudub üksmeel selles, millised oskused ja võimed on tekstist arusaamisel kõige olulisemad. Algkoolis loetakse määravaks morfeemiteadlikkust, elementaarset lugemisoskust, lugemise täpsust, keelelist võimekust, üldist võimete taset, sõnavara ja töömälu (Catts \& Ellis Weismer, 2006; Cutting \& Scarborough, 2006; Goff, Pratt \& Ong, 2005; Jongejan, Verhoeven, \& Siegel, 2007; Kirby et al., 2012; Männamaa \& Kikas, 2010; Soodla \& Kikas, 2010). Tekstimõistmise heaks ennustajaks peetakse verbaalseid võimeid (Berninger, Abbott, Vermeulen, \& Fulton, 2006; Echols, West, Stanovich, \& Zehr, 1996; Pečjak, Podlesek, \& Pirc, 2011), seda nii algklasside kui ka keskastme õpilaste puhul (Reynolds \& Turek, 2012). Uuritud on tekstimõistmise komponentide (info äratundmise ja integreerimise ning sõnatähenduse tundmise) osa tekstist arusaamisel. Verbaalselt võimekamad ja parema tekstimõistmisoskusega õpilased kodeerivad ja integreerivad tekstipõhist infot edukamalt (Schroeder, 2011). Lapsed, kellel on raskusi teksti mõistmisega, meenutavad tekstis sisalduvat infot ebatäpsemalt ja teevad info integreerimisel rohkem vigu kui eakaaslased, kellel tekstist arusaamisega probleeme ei ole (Carretti, Cornoldi, De Beni, \& Romano, 2005).

Loetust arusaamist mõjutavad tugevalt sõnavara ja eelteadmised (Broek \& Espin, 2012; McKeown \& Beck, 2004). Eelteadmised võimaldavad luua seoseid tuttava ja uue info vahel ning lihtsustada teksti mõistmist (Saxton, 2010; Schroeder, 2011). Tekstimõistmist hõlbustab ka sõnatähenduse, süntaktiliste ja grammatiliste konstruktsioonide tundmine (Cain \& Oakhill, 2007, 2011; Sinka, 2008) ning võime infot töödelda ja üle kanda (Krashen, 1982; Lenneberg, 1967). Selleks, et õpilane loetust aru saaks, tuleks arendada muu hulgas kriitilise mõtlemise ja järeldamise oskust (Connor \& Al'Otaiba, 2008).

Samas pole leitud kindlat võimete ja oskuste profiili, mis viitaks lugemisraskustele, sh loetu mõistmisel (Watson et al., 2003). Lugemisraskused võivad selguda hiljem, ka siis, kui laps on olnud koolis edukas (Leach, Scarborough, \& Rescorla, 2003).

\section{Muutused õpilaste tekstimõistmises}

Varasemates uurimustes on leitud, et laste tekstimõistmise probleemid on ajas võrdlemisi püsivad (Kim, Samson, Fitzgerald, \& Hartry, 2009; Nation, Cocksey, Taylor, \& Bishop, 2010) ning erinevused võimekamate ja vähem võimekamate laste vahel ajas pigem suurenevad, st võimekamate 
tulemused paranevad ja nõrgemate omad halvenevad veelgi (Cain \& Oakhill, 2011; Kempe, Eriksson-Gustavsson, \& Samuelsson, 2011). Samas on uurimusi, mis näitavad laste akadeemilise edukuse muutumist ajas. Juel (1988) leidis, et 1. klassis kehval või keskmisel lugejal on suurem tõenäosus püsida 4 . klassis samas tasemerühmas kui olla tugevamate seas ning ligi 2/3 kehvadest 3. klassi lugejatest püsib samal tasemel ka 9. klassis. Phillipsi, Norrise, Osmondi ja Maynardi uurimuse (2002) järgi jäi ligi $70 \%$ 6. klassi õpilastest samasse akadeemilise edukuse rühma (madal, keskmine, kõrge tase) kui 1. klassis; 30\% lastest rühmakuuluvus muutus. Muutusi keelelistes osaoskustes on leitud nii väikese, keskmise kui ka suure võimekusega algklassiõpilastel, kusjuures keskmise ja keskmisest väiksema võimekusega õpilaste tulemused ajas paranesid, ning võimekamate õpilaste seas oli lapsi, kelle tulemused hoopis halvenesid (Mooij \& Driessen, 2008).

Akadeemilise edukuse, sh muutuste hindamisel on oluline arvestada muutustega õpilase verbaalsetes võimetes ning akadeemilise edukuse ja võimete seostega. Seejuures tuleks nende seoste interpreteerimisel hinnata ka individuaalseid erinevusi (Primrose, Fuller, \& Littledyke, 2000).

\section{Õpetamistegevused ja õpilaste tekstimõistmine}

On leitud, et õpetaja tegevused avaldavad mõju õpilaste tekstimõistmisoskusele (Gleason \& Ratner, 2009; Saxton, 2010). Tekstist arusaamist on võimalik parandada sobivate strateegiatega, nt jagatud lugemine (shared reading), vastastikune õpetamine (reciprocal teaching) (Fisher, Frey, \& Lapp, 2008; Johnson-Glenberg, 2000), otsene õpetamine (direct instruction), küsimuste esitamine ja neile vastamine (Gleason \& Ratner, 2009; Perry et al., 2007). Kuna elementaarne lugemisoskus baseerub eelkõige tähelepanul, töömälul ja meelespidamisel, eeldab selle arendamine formaalsete õpetamistegevuste (nt harjutamise, kordamise, meenutamise) kasutamist (Gleason \& Ratner, 2009; Saxton, 2010). Loetust arusaamist toetavad tegevused, mis on suunatud info integreerimisele, sõnatähenduse leidmisele, oskusele sõnastada ümber mõtteid, järeldada ja põhjendada arvamust (Krathwohl, 2002; Saxton, 2010). Olulisel kohal on strateegiad, mis toetavad kõrgema taseme mõtlemisoskusi (nt analüüsimine, seostamine, üldistamine) (Krathwohl, 2002; Perry et al., 2007).

Keskendumine tekstipõhise info kodeerimisele ja meenutamisele on vajalik eelkõige esimeses kooliastmes, kus omandatakse sõnavara ja elementaarne lugemisoskus (Gleason \& Ratner, 2009). Teises kooliastmes muutuvad tekstid keerukamaks, suureneb mõistete hulk, lugemise 
eesmärk on omandada uusi teadmisi. Häid tulemusi annab info ülekandmise ja järeldamisoskuse arendamine (Lenneberg, 1967; Mayer, 2002). Samas on tähtis mõisteid korrata (Hollingsworth \& Hoover, 1991), sest sõnavara omandamine on suhteliselt aeglane protsess (Cain \& Oakhill, 2011) ja kinnistamata sõnatähendused raskendavad teksti mõistmist (Cain \& Oakhill, 2007; Gleason \& Ratner, 2009). Sobivateks strateegiateks peetakse süstemaatilist sõnavara arendamist, arusaamise jälgimist ja kontrollimist ning arutelusid (Connor \& Al'Otaiba, 2008; Krashen, 1982).

Õpetajate õpetamistegevuste eelistused ei seostu aga ainult õpilaste individuaalsete erinevuste, vanuse ja kooliastmega, vaid on mõjutatud õpetaja isiksuslikest ja professionaalsetest näitajatest (nt eelistused, töökogemus), õppekava eesmärkidest ja nõudmistest (Kyriacides, Campbell, \& Christofidou, 2002). Siinses uurimuses analüüsitakse muu hulgas interaktsiooni õpilaste tekstimõistmise komponentide ja õpetajaid iseloomustavate tunnuste vahel.

\section{Empiiriline uurimus}

\section{Eesmärgid ja hüpoteesid}

Õpetajad arendavad õpilaste vaimseid võimeid ja keelelisi osaoskusi, kasutades erinevaid õpetamistegevusi (Foorman et al., 2006; Uibu, Kikas, \& Tropp, 2010). Suur osa senistest tekstimõistmise uurimustest on läbilõikelised, õpetamistegevuste mõju õpilaste tekstimõistmise muutusele on vähem uuritud. Veelgi vähem on uuritud erineva kooliastme õpilaste tekstimõistmist ja verbaalset võimekust koos õpetajate tegevuste stabiilsuse ja muutusega. Praeguse pikiuurimuse eesmärk oli välja selgitada erinevused õpilaste tekstimõistmises ja verbaalsetes võimetes põhikooli esimeses ja teises kooliastmes ning nende seos klassiõpetajate õpetamistegevustega. Peale rühmataseme erinevuste selgitati välja ka erinevused õpilaste tekstimõistmise ja õpetajate õpetamistegevuste profiilirühmades. Uurimuses püstitati järgmised ülesanded ja hüpoteesid.

1. Analüüsida tekstimõistmise komponentide ja verbaalsete võimete seoseid. Varasemates uurimustes on leitud, et verbaalsed võimed seostuvad sõnatähenduse tundmisega (Cain \& Oakhill, 2011; Saxton, 2010) ning õpilased, kelle verbaalsed võimed on paremad, saavad loetust paremini aru (Schroeder, 2011). Oletasime, et õpilaste tekstimõistmise komponentide (info äratundmise, info integreerimise, sõnatähenduse tundmise) ja verbaalse võimekuse vahel ilmnevad seosed. Erinevalt 
varasematest uurimustest hindame erinevate tekstimõistmise komponentide ja verbaalse võimekuse seoseid kompleksselt.

2. Selgitada välja erinevused poiste ja tüdrukute tekstimõistmises. On leitud, et tüdrukute tekstimõistmine on oluliselt parem kui poistel (Sinka, 2008; Tire et al., 2010; Uibu \& Tropp, 2013). Oletasime, et üleminekul esimesest kooliastmest teise astmesse püsivad erinevused poiste ja tüdrukute tekstimõistmises.

3. Hinnata klassiõpetajate õpetamistegevuste eelistusi. Kuna õpilaste kognitiivsete oskuste, sh keeleoskuse areng esimeses ja teises kooliastmes on kiire (Saxton, 2010), peaksid õpetajad varieerima õpetamistegevusi, lähtudes õpilaste arengust (Foorman et al., 2006). Algkoolis kujundatakse elementaarne lugemisoskus, mis nõuab rohkem mehaanilisi tegevusi, sh kordamist ja harjutamist. Tekstimõistmise arendamine teises kooliastmes eeldab arusaamise, info analüüsimise ja ülekandmise oskuste toetamist (Gleason \& Ratner, 2009; Mayer, 2002). Oletasime, et 3. ja 4. klassi võrdluses ilmnevad erinevused ópetajate õpetamistegevustes, sest 4 . klassis muutub õppematerjal keerukamaks ning see nõuab teistsuguste tegevuste kasutamist.

4. Leida õpilaste tekstimõistmise individuaalsed profilid ja analüüsida nende stabiilsust ajas. Varasemates uurimustes on leitud, et õpilaste profiilid võivad olla nii stabiilsed kui ka muutuvad (Männamaa \& Kikas, 2010; Uibu \& Tropp, 2013). Õpilaste võimete ja oskuste arengus on individuaalsed erinevused (Männamaa \& Kikas, 2010), mida mõjutavad muu hulgas õpetamistegevused (Gleason \& Ratner, 2009). Eeldasime, et üleminekul esimesest kooliastmest teise astmesse toimuvad muutused õpilaste tekstimõistmises ja verbaalses võimekuses (Gleason \& Ratner, 2009).

5. Selgitada välja erineva ópetamistegevuste profiliga õpetajate rühmad ja analüüsida ópetamistegevuste profilide muutust ajas. Erinevate õpetamistegevuste kasutamine on oluline õpilaste arengu kontekstis, seepärast peaksid õpetajad ühendama mehaanilise õpetamise, mõistmise arendamise ja praktilised tegevused (Schuh, 2004). On leitud, et sama kooliastme õpetajad erinevad oma õpetamistegevuste poolest (Schepens, Aeltermann, \& Van Keer, 2007; Uibu et al., 2010). Oletasime, et klassiõpetajate puhul eristuvad profilirühmad, mida iseloomustab nt 1) mehaaniline õpetamine; 2) mõistmise arendamine; 3) teadmiste praktiline rakendamine; 4) kombineeritud profiil. Samuti eeldasime, et 3. ja 4. klassi võrdluses muutub õpetajate profiil ja erinevate profilirühmade vahel avalduvad suuremad erinevused kui kogu valimi puhul. 
6. Analüüsida õpetajate õpetamistegevuste mõju õpilaste tekstimõistmisele. Toetudes varasematele uurimustele (Foorman et al., 2006; Uibu et al., 2010), püstitasime hüpoteesi, et erineva ópetamistegevuste profiiliga õpetajate õpilased erinevad tekstimõistmise komponentide taseme poolest. Oletasime, et arusaamisele suunatud tegevusprofiliga õpetajate õpilased saavutavad tekstimõistmises paremaid tulemusi (Gleason \& Ratner, 2009). Seevastu mehaanilist õpetamist eelistavate õpetajate õpilastel on paremad tulemused sõnatähenduse tundmises, sest sõnavara omandamine nõuab kordamist ja kinnistamist (Cain \& Oakhill, 2011; Hollingsworth \& Hoover, 1991).

\section{Meetod}

\section{Valim}

Uurimuses osalenud õpilaste ja klassiõpetajate andmed koguti mahukama uurimisprojekti raames (Toomela, 2010). Pikiuurimuse valimisse (3.-5. klassis) kuulus 844 õpilast ja 48 klassiõpetajat 28 Eesti põhikoolist. Valimisse kaasati võimalikult erinevad koolid, arvestades nende piirkondlikku paiknemist ja asukohta (maa- ja linnakool), kooli tüüpi (põhikool ja gümnaasium), klassi suurust (väikesed ja suured klassid, liitklassid). Kõik õpilased õppisid Eesti põhikooli ja gümnaasiumi riikliku õppekava (2007) järgi. Siinses artiklis analüüsitakse nende õpilaste andmeid, kes sooritasid verbaalsete võimete ja emakeeletesti 4. ja 5. klassis, ja nende klassiõpetajate andmeid, kes täitsid õpetamistegevuste küsimustiku 3. ja 4. klassis.

Õpilaste verbaalseid võimeid ja tekstimõistmist mõõdeti kahel korral: 4. ja 5. klassi sügisel. Õpilasi, kes täitsid verbaalsete võimete ja emakeeletesti mõlemas klassis, oli kokku 609, neist $293(48,1 \%)$ poisid ja 316 (51,9\%) tüdrukud. Õpilaste keskmine vanus 4. klassi sügisel oli 10,00 aastat, $S D=0,36$, ning 5. klassi sügisel 10,98 aastat, $S D=0,37$.

Klassiõpetajate õpetamistegevusi mõõdeti 3. ja 4. klassis sügisel. Õpetajaid, kes täitsid küsimustiku mõlemal korral, oli kokku 36 ja nad õpetasid valimisse kuulunud õpilastele emakeelt 1.-4. klassis. Õpetajate keskmine vanus oli 43,64 aastat, $S D=7,78(N=35$; $\min =26$ aastat; $\max =61$ aastat), keskmine õpetamiskogemus 18,78 aastat, $S D=9,69(N=36, \min =1$; $\max =39$ ). 


\section{Protseduur ja mõõtevahendid}

Õpilaste tekstimõistmist ja verbaalseid võimeid hinnati kahe eraldi testiga. Emakeeletest saadeti koolidesse postiga kinnistes ümbrikes, testi viisid läbi selles klassis emakeelt õpetanud õpetajad eesti keele tunni ajal. Verbaalsete võimete testi täitsid õpilased klassis ja testi viis läbi projekti uurija. Õpilastel kulus mõlema testi täitmiseks kokku üks ainetund (45 minutit).

Emakeeletest sisaldas tekstimõistmise ülesandeid, millega hinnati erinevaid tekstimõistmise komponente (info äratundmist ja integreerimist, semantilist pädevust ja sõnatähenduse tundmist). Testi väljatöötamisel võeti aluseks Bloomi hierarhilise taksonoomia edasiarendus (Krathwohl, 2002; Mayer, 2002), emakeele ainekava nõudmised ja riiklikud tasemetööd (vt Uibu et al., 2010; Uibu \& Tropp, 2013). 4. ja 5. klassi emakeeletestid koosnesid 14 ülesandest. Info äratundmise ülesannetes (5 ülesannet) tuli õpilastel läbi lugeda seotud tekst (valm) ja otsustada, kas etteantud laused vastavad teksti sisule või mitte. Lause, mis ei olnud sisu järgi õige, tuli läbi kriipsutada. Info integreerimise ülesannetes (5 ülesannet) pidi õpilane ühendama kaks osalauset, mis kuulusid sisult kokku. Morfoloogiliselt ja süntaktiliselt ühildusid kõik kõrvallaused eelneva pealausega. Sõnatähenduse tundmise ülesannetega (4 ülesannet) kontrolliti semantilist pädevust: õpilane pidi leidma tekstis esinenud sõnadele etteantud loendist sobiva sünonüümi (nt kohmakas - saamatu). Peale õige tähendusega sõnade (10) sisaldas loend ka väära tähendusega sõnu ja sõnaühendeid (9). Õiged vastused kodeeriti mõlemas klassis 1ga, valed või märkimata vastused 0ga. Iga tekstimõistmise komponendi kohta arvutati õigete vastuste koondskoor; ülesannete sisereliaablus (Cronbachi alfa) oli 4. ja 5. klassis vastavalt 0,74 ja 0,84 (info äratundmine), 0,86 ja 0,89 (info integreerimine), 0,89 ja 0,80 (sõnatähenduse tundmine).

Mõistete äraarvamise testiga mõõdeti õpilaste verbaalset võimekust ja järeldamisoskust ning info integreerimise võimet. Testi koostamisel võeti aluseks õppekava nõuded (Vabariigi Valitsus, 2007) ja ülesannetes küsiti mõisteid, mis olid õpilasele tuttavad igapäevaelust ja õpikutekstidest. Õpilane pidi kolme iseloomuliku vihje alusel ära arvama sobiva mõiste või sõna (Männamaa, Kikas, \& Raidvee, 2008). Testi lahendamise edukus oli seotud sõnavara, töömälu, tähelepanu, üldise võimekuse, mitteverbaalse järeldamisoskuse ja loogilise deduktsiooniga (Männamaa \& Kikas, 2010). Uurimuses kasutati testi lühiversiooni, kus lapsele esitati paberil kuus ülesannet. Vastus loeti õigeks siis, kui laps pani kirja täpse sõna. Näiteks, õige vastus ülesandele „Mis on hästi vana mäng, mida mängitakse 
ruudulisel laual erikujuliste nuppudega?” on „male”. Testi koondskooriks oli õigete vastuste summa, vastuste skoorimisel ei arvestatud kirjavigu. Testi sisereliaablus oli suur: 4. klassis $\alpha=0,82$ ja 5 . klassis $\alpha=0,80$.

Õpetamistegevuste küsimustikku kasutati õpetajate enesekohaste hinnangute mõõtmiseks oma õpetamistegevuste kohta (Uibu et al., 2010; Uibu, Kikas, \& Tropp, 2011). Kyriacidese jt (2002) järgi on hinnangute ja tegevuste vahel tugev seos: õpetajad hindavad kõrgemalt tegevusi, mida nad ise õppeprotsessis kasutavad. Õpetajatel oli võimalik täita küsimustik kas elektrooniliselt või paberil. Elektroonilise küsimustiku täitis 21 õpetajat, ülejäänud eelistasid uurimisrühma liikmelt saadud paberversiooni. Küsimustik sisaldas 21 väidet, mis kirjeldasid kolme õppimise ja lapse arenguga seotud õpetamistegevuste valdkonda. Mehaanilise ópetamise skaala (7 väidet) sisaldas õpilaste teadmiste mehaanilisele omandamisele, info meeldejätmisele ja mälule suunatud õpetamistegevusi (nt „Lasen õpilastel õppida pähe fakte, definitsioone ja reegleid"). Mõistmise skaala (9 väidet) sisaldas tegevusi õpilaste kriitilise mõtlemise, arusaamise ja info tõlgendamise arendamiseks (nt „Analüüsin koos õpilastega ülesannete lahenduskäiku ja vastuseid, et nad saaksid õpitavast paremini aru”). Rakendamise skaala (5 väidet) hõlmas kirjeldusi info integreerimise ja teadmiste praktilise rakendamise kohta (nt „Teen koos õpilastega praktilisi ülesandeid, et õpetada neid omandatud teadmisi kasutama"). Õpetajad hindasid Likerti skaalal ( 1 - üldse mitte, 2 - mitte rohkem kui kord kuus, 3 - kaks korda kuus, 4 - üks kord nädalas, 5 - peaaegu iga päev), kui sageli nad kirjeldatud õpetamistegevusi kasutavad. Varasemas uurimuses on skaalade sisereliaablus hinnatud aktsepteeritavaks: 3 . klassis $0,65-0,69$ ja 4. klassis 0,60-0,67 (Uibu et al., 2010).

\section{Andmeanalüïs}

Andmete analüüsimisel kasutati nii rühma- kui ka indiviidikeskseid meetodeid. Rühmakesksed analüüsid võimaldavad võrrelda omavahel uuritavaid, eeldusel et valim on homogeenne ning individuaalsed erinevused võivad kaduma minna (Cohen, Manion, \& Morrison, 2007). Indiviidikeskne käsitlusviis baseerub eeldusel, et kogu valim ei pruugi olla homogeenne: selles võivad esineda sarnaste indiviidide alarühmad ning nende vahel on erinevused, mida on võimalik välja selgitada (Bergman, Magnusson, \& El-Khouri, 2003).

Seoseid tekstimõistmise komponentide ja verbaalse võimekuse vahel analüüsiti statistikapaketiga SPSS Statistics (versioon 20.0), kasutades 
Pearsoni lineaarkorrelatsiooni kordajat. Erinevuste väljaselgitamiseks õpilaste ja õpetajate rühmades tehti kirjeldavad analüüsid. Poiste ja tüdrukute tekstimõistmise komponentide võrdlemiseks kasutati ühefaktorilist dispersioonanalüüsi (one-way ANOVA). Statistilist olulisust rühmade vahel esitleti peale $p$-väärtuse ka osalise efekti suurusega $\eta^{2}$ (edaspidi: $\eta^{2}$ ): 0,01 - väike efekt; 0,06 - keskmine efekt; 0,14 - suur efekt (Cohen et al., 2007). Õpetajate õpetamistegevuste eelistuste võrdlemiseks kasutati mitteparameetrilisi Friedmani ja Wilcoxoni teste.

Õpilaste tekstimõistmise profiilide ja õpetajate õpetamistegevuste profiilide väljaselgitamiseks kasutati SLEIPNER 2.1 statistikatarkvara paketti kuuluvat CLUSTERi moodulit ja Wardi meetodit (Bergman et al., 2003). Klasterlahenduse valikul arvestati järgmisi kriteeriume: 1) teoreetilist põhjendust, 2) EESS-näitajat, 3) klastrite homogeensust (Bergman et al., 2003). Kompleksseid seoseid uuriti konfiguratsioonilise sagedusanalüüsiga (KSA) (CFA, versioon 2000; von Eye, 2000), mis võimaldab andmeid üldistamata välja selgitada, kas teatud tunnuste kombinatsiooniga juhtusid esineb valimis sagedamini, kui võiks esineda juhuslikult (tüüp), või esineb harvemini, kui võiks esineda juhuslikult (antitüüp) (Bergman et al., 2003; von Eye, 2000). Õpilaste soolise jaotuse analüüsimiseks profiilirühmades kasutati kahe valimi KSAd (two-sample CFA), mis võimaldab võrrelda kahte sõltumatute valimite rühma ning selgitada välja diskriminatsioonitüübid. Muutust õpilaste tekstimõistmise individuaalsetes profiilides analüüsiti esimest liiki KSA Pearsoni $\chi^{2}$ testiga; stabiilsust õpetajate õpetamistegevuste rühmades binominaalse testiga (von Eye, 2000). Õpetajate profiilirühmade vaheliste erinevuste väljaselgitamiseks vanuse ja töökogemuse järgi kasutati Kruskali-Wallise testi. Tüüpilised õpetamistegevuste profiilid, mis olid statistiliselt oluliselt seotud õpilaste tekstimõistmise ning selle muutusega 4. ja 5. klassis, selgitati välja esimest liiki KSA Pearsoni $\chi^{2}$ testiga.

\section{Tulemused}

\section{Tekstimõistmise komponentide ja verbaalse võimekuse seosed}

Et hinnata seoseid tekstimõistmise komponentide ja verbaalse võimekuse vahel, kasutati Pearsoni lineaarkorrelatsiooni kordajat (tabel 1). 
Tabel 1. Korrelatsioonid tekstimõistmise komponentide ja verbaalse võimekuse vahel

\begin{tabular}{l|c|c|c|c|c|c|c}
\hline \multirow{2}{*}{$\begin{array}{l}\text { Tekstimõistmise } \\
\text { komponendid }\end{array}$} & \multicolumn{3}{|c|}{4. klass } & \multicolumn{3}{|c}{5. klass } \\
\cline { 2 - 8 } & $\mathbf{2}$ & $\mathbf{2}$ & $\mathbf{3}$ & $\mathbf{4}$ & $\mathbf{5}$ & $\mathbf{6}$ & $\mathbf{7}$ \\
\hline 4. klass & - & & & & & & \\
\hline Info äratundmine (1) & 0,25 & - & & & & & \\
Info integreerimine (2) & 0,36 & 0,41 & - & & & & \\
Sõnatähenduse tundmine (3) & 0,39 & 0,39 & 0,48 & - & & & \\
Verbaalsed võimed (4) & & & & & & & \\
\hline 5. klass & 0,29 & 0,20 & 0,31 & 0,37 & - & & \\
\hline Info äratundmine (5) & 0,31 & 0,40 & 0,40 & 0,43 & 0,39 & - & \\
Info integreerimine (6) & 0,29 & 0,37 & 0,54 & 0,49 & 0,42 & 0,45 & - \\
Sõnatähendus (7) & 0,30 & 0,41 & 0,47 & 0,63 & 0,41 & 0,43 & 0,49 \\
Verbaalsed võimed (8) & & & & & & & \\
\hline
\end{tabular}

Märkus. Kõik tabelis esitatud väärtused on statistiliselt olulised, $p<0,001$.

Statistiliselt olulised seosed leiti 4. ja 5. klassis kõikide tekstimõistmise komponentide ja verbaalse võimekuse vahel. Seejuures leiti tugev seos ( $r>0,6$ olulisusnivool $p<0,001$ ) (vt Cohen et al., 2007) mõlema mõõtmishetke verbaalsete võimete vahel. Tugevamalt korreleerusid ka sõnatähenduse tundmine 4. ja 5. klassis ning verbaalsed võimed ja sõnatähenduse tundmine 4. ja 5. klassis. Mõõdukad seosed ( $r>0,35$ olulisusnivool $p<0,001)$ avaldusid õpilaste verbaalsete võimete ja info äratundmise vahel, samuti verbaalsete võimete ja info integreerimise ülesannete vahel nii 4. kui ka 5. klassis. Lisaks seostusid 4. klassi õpilaste verbaalsed võimed mõõdukalt info äratundmise ja info integreerimisega 5. klassis. Analoogilised seosed leiti veel 4. ja 5. klassis sõnatähenduse tundmise ja info äratundmise ülesannete vahel, samuti sõnatähenduse tundmise ja info integreerimise ülesannete vahel.

\section{Soolised erinevused õpilaste tekstimõistmises ja verbaalsetes võimetes}

Poiste ja tüdrukute tekstimõistmise komponentide ja verbaalse võimekuse hindamiseks tehti esmalt kirjeldavad analüüsid (tabel 2). 
Tabel 2. Tekstimõistmise komponentide ja verbaalse võimekuse keskmised väärtused ja standardhälbed

\begin{tabular}{l|c|c|c|c|c|c|c|c}
\hline & \multicolumn{4}{|c|}{$\begin{array}{c}\text { Poisid } \\
(N=\mathbf{2 9 3})\end{array}$} & \multicolumn{4}{c}{$\begin{array}{c}\text { Tüdrukud } \\
(N=316)\end{array}$} \\
\cline { 2 - 10 } $\begin{array}{l}\text { Tekstimõistmise } \\
\text { komponendid }\end{array}$ & $\mathbf{4 . \text { klass }}$ & \multicolumn{2}{|c|}{$\mathbf{5 . \text { klass }}$} & \multicolumn{3}{c}{ 4. klass } & \multicolumn{2}{c}{ 5. klass } \\
\cline { 2 - 10 } & $M$ & $S D$ & $M$ & $S D$ & $M$ & $S D$ & $M$ & $S D$ \\
\hline Info äratundmine & 4,24 & 1,04 & 4,33 & 1,12 & 4,39 & 0,98 & 4,55 & 0,86 \\
\hline Info integreerimine & 3,09 & 1,72 & 3,68 & 1,55 & 3,46 & 1,54 & 4,10 & 1,37 \\
\hline Sõnatähenduse tundmine & 2,81 & 1,31 & 2,79 & 1,19 & 3,34 & 1,15 & 3,18 & 1,06 \\
\hline Verbaalsed võimed & 2,94 & 1,82 & 3,55 & 1,76 & 3,53 & 1,72 & 3,99 & 1,54 \\
\hline
\end{tabular}

Erinevusi poiste ja tüdrukute vahel analüüsiti 2 (sugu) $\times 4$ (tekstimõistmise komponent) ühefaktorilise dispersioonanalüüsiga (one-way ANOVA). Ilmnes, et 4. klassis olid tüdrukute tulemused statistiliselt oluliselt paremad kui poistel: sõnatähenduse tundmises, $F(1,607)=27,54$, $p<0,001, \eta^{2}=0,043$; verbaalsetes võimetes, $F(1,607)=17,83, p<0,001$, $\eta^{2}=0,028$; info integreerimises, $F(1,607)=8,13, p=0,005, \eta^{2}=0,013$. Tüdrukute paremus poiste suhtes ei ilmnenud 4 . klassis aga tekstist info äratundmises, $p=0,062$. Võrreldes poiste ja tüdrukute tulemusi 5. klassis, leiti olulised erinevused kõikide ülesannete vahel: sõnatähenduse tundmises, $F(1,607)=18,47, p<0,001, \eta^{2}=0,03$; info integreerimises, $F(1,607)=12,94, p=0,001, \eta^{2}=0,021$; verbaalsetes võimetes, $F(1$, $607)=10,88, p=0,001, \eta^{2}=0,018$; info äratundmises, $F(1,607)=7,01$, $p=0,008, \eta^{2}=0,011$.

\section{Õpetajate õpetamistegevused}

Et selgitada välja õpetajate õpetamistegevuste eelistused, tehti kõigepealt kirjeldavad analüüsid (tabel 3).

Tabel 3. Õpetamistegevuste kirjeldavad näitajad 3. ja 4. klassis

\begin{tabular}{l|c|c|c|c|c|c|c|c}
\hline & \multicolumn{3}{|c|}{$\begin{array}{c}\text { 3. klass } \\
(N=36)\end{array}$} & \multicolumn{3}{c|}{$\begin{array}{c}\text { 4. klass } \\
(N=36)\end{array}$} & \multicolumn{2}{c}{} \\
\cline { 2 - 10 } Õpetamistegevus & $M$ & $S D$ & $\begin{array}{c}\text { Keskmine } \\
\text { astak }\end{array}$ & $M$ & $S D$ & $\begin{array}{c}\text { Keskmine } \\
\text { astak }\end{array}$ & $z$ & $p$ \\
\hline Mehaaniline õpetamine & 3,19 & 0,58 & 1,11 & 3,53 & 0,50 & 1,18 & $-3,46$ & 0,001 \\
\hline Mõistmine & 4,21 & 0,41 & 2,35 & 4,21 & 0,42 & 2,49 & $-0,02$ & 0,99 \\
\hline Rakendamine & 4,25 & 0,55 & 2,54 & 4,11 & 0,53 & 2,33 & $-1,44$ & 0,15 \\
\hline
\end{tabular}


Seejärel võrreldi õpetajate õpetamistegevuste eelistusi eraldi 3. ja 4. klassis, kasutades mitteparameetrilist Friedmani testi. Selgus, et 3. klassis erinesid õpetajad oma eelistustelt statistiliselt oluliselt, $\chi^{2}=44,27, d f=2$, $p<0,001$. Paariti võrdlusest Wilcoxoni testiga ilmnes, et õpetajad eelistasid mehaanilisele õpetamisele mõistmise arendamist, $z=-4,93, N=36$, $p<0,001$, ja teadmiste rakendamist, $z=-4,76, N=34, p<0,001$. Võrreldes õpetajate õpetamistegevusi 4 . klassis, leiti nende vahel samuti statistiliselt oluline erinevus, $\chi^{2}=36,94, d f=2, p<0,001$. Sama moodi nagu 3. klassi puhul, eelistasid õpetajad siingi rohkem mõistmise arendamist, $z=-5,01, N=35, p<0,001$, ja teadmiste rakendamist, $z=-4,57, N=36$, $p<0,001$, mitte mehaanilist õpetamist.

Järgnevalt hinnati Wilcoxoni testiga muutust õpetajate õpetamistegevustes (tabel 3). 4. klassis kasutati 3. klassiga võrreldes oluliselt rohkem mehaanilist õpetamist. Teiste õpetamistegevuste - mõistmise arendamise ja teadmiste rakendamise - vahel kahel mõõtmishetkel statistiliselt olulist erinevust ei leitud.

\section{Õpilaste tekstimõistmise ja õpetajate õpetamistegevuste profiilid}

Indiviidikeskse käsitlusviisiga sooviti selgitada välja süstemaatilised erinevused õpilaste tekstimõistmise komponentides ja muutus üleminekul esimesest kooliastmest teise astmesse ning õpetajate õpetamistegevuste mõju õpilaste tekstimõistmisele (Bergman et al., 2003). Selleks kitsendati valimit, analüüsides järgnevalt vaid neid õpilasi $(N=472)$, keda õpetasid pikiuurimuses osalenud klassiõpetajad 3. ja 4. klassis $(N=36)$ ning kes olid täitnud õpetamistegevuste küsimustiku mõlemal aastal.

Õpilaste profilid. Kasutades hierarhilist klasteranalüüsi (CLUSTERi moodul, Wardi meetod), jaotati õpilased tekstimõistmise ja verbaalsete võimete ülesannete standardiseeritud tulemuste põhjal klastritesse. Nii 4. kui ka 5. klassis valiti kuueklastriline lahendus: 4. klassis EESS $=63,48$ ja homogeensus $<1,29$; 5 . klassis EESS $=62,83$ ja homogeensus $<1,74$. Klastrite kirjeldused on esitatud tabelis 4. 
Tabel 4. Tekstimõistmise profillide kirjeldavad näitajad

\begin{tabular}{|c|c|c|c|c|c|c|c|c|c|c|}
\hline \multirow{3}{*}{$\begin{array}{l}\text { Klaster } \\
\text { 4. klass } \\
\text { KL 4-1 }\end{array}$} & & & \multicolumn{2}{|c|}{$\begin{array}{c}\text { Info } \\
\text { äratundmine }\end{array}$} & \multicolumn{2}{|c|}{$\begin{array}{c}\text { Info } \\
\text { integreeri- } \\
\text { mine }\end{array}$} & \multicolumn{2}{|c|}{$\begin{array}{l}\text { Sõna- } \\
\text { tähenduse } \\
\text { tundmine }\end{array}$} & \multicolumn{2}{|c|}{$\begin{array}{l}\text { Verbaalsed } \\
\text { võimed }\end{array}$} \\
\hline & \multicolumn{2}{|c|}{$N=472$} & M & $S D$ & M & $S D$ & $M$ & $S D$ & $M$ & $S D$ \\
\hline & 45 & $9,5 \%$ & 4,47 & 0,59 & 2,82 & 1,84 & 0,98 & 0,84 & 1,91 & 1,41 \\
\hline KL 4-2 & 97 & $20,6 \%$ & 4,91 & 0,28 & 4,53 & 1,41 & 3,57 & 0,56 & 2,33 & 0,91 \\
\hline KL 4-3 & 176 & $37,3 \%$ & 4,61 & 0,71 & 5,65 & 0,58 & 3,64 & 0,66 & 4,85 & 0,86 \\
\hline KL 4-4 & 38 & $8,1 \%$ & 2,58 & 0,79 & 1,92 & 1,36 & 1,00 & 1,04 & 0,79 & 0,81 \\
\hline KL 4-5 & 60 & $12,7 \%$ & 4,92 & 0,28 & 2,87 & 1,07 & 3,75 & 0,54 & 4,68 & 0,72 \\
\hline KL 4-6 & 56 & $11,9 \%$ & 2,93 & 0,99 & 3,54 & 1,25 & 3,43 & 0,74 & 2,36 & 1,27 \\
\hline \multicolumn{11}{|l|}{ 5. klass } \\
\hline KL 5-1 & 31 & $6,6 \%$ & 3,97 & 0,95 & 1,23 & 0,72 & 1,48 & 1,03 & 1,52 & 1,12 \\
\hline KL 5-2 & 103 & $21,8 \%$ & 4,84 & 0,36 & 4,72 & 0,45 & 3,63 & 0,48 & 3,24 & 0,94 \\
\hline KL 5-3 & 176 & $37,3 \%$ & 4,84 & 0,37 & 4,64 & 0,68 & 3,77 & 0,42 & 5,26 & 0,54 \\
\hline KL 5-4 & 19 & $4,0 \%$ & 1,32 & 0,89 & 1,84 & 1,39 & 1,05 & 0,97 & 1,37 & 1,46 \\
\hline KL 5-5 & 73 & $15,5 \%$ & 4,25 & 0,98 & 2,51 & 1,35 & 2,99 & 0,70 & 3,81 & 1,13 \\
\hline KL 5-6 & 70 & $14,8 \%$ & 4,57 & 0,55 & 4,44 & 0,74 & 1,76 & 0,73 & 3,47 & 1,69 \\
\hline
\end{tabular}

Profiilide tõlgendamisel võeti aluseks muutuja standardiseeritud skoor: keskmine skoor vahemikus $-0,50$ kuni 0,50 ; suur $>0,50$; väike $<-0,50$. Kõigi kuue profiilirühma õpilastel oli ühe või mitme tekstimõistmise komponendi ja verbaalse võimekuse skoor oluliselt suurem või väiksem kui teiste rühmade õpilastel (tabel 5). 
Tabel 5. Tekstimõistmise ja verbaalse võimekuse profiilide kirjeldused standardiseeritud skooride järgi

\begin{tabular}{|c|c|c|c|c|c|c|c|c|c|}
\hline \multirow[b]{2}{*}{ Klaster } & \multirow{2}{*}{$\begin{array}{l}\text { Profiili } \\
\text { kirjeldus }\end{array}$} & \multicolumn{2}{|c|}{$\begin{array}{c}\text { Info } \\
\text { äratundmine }\end{array}$} & \multicolumn{2}{|c|}{$\begin{array}{l}\text { Info inte- } \\
\text { greerimine }\end{array}$} & \multicolumn{2}{|c|}{$\begin{array}{l}\text { Sõnatähen- } \\
\text { duse tund- } \\
\text { mine }\end{array}$} & \multicolumn{2}{|c|}{$\begin{array}{l}\text { Verbaalsed } \\
\text { võimed }\end{array}$} \\
\hline & & $M$ & $T R$ & $M$ & $T R$ & $M$ & $T R$ & $M$ & $T R$ \\
\hline \multicolumn{10}{|l|}{ 4. klass } \\
\hline KL 4-1 & Madal $_{\text {dom }}$ & 0,38 & Keskmine & $-0,55$ & Madal & $-1,29$ & Madal & $-0,56$ & Madal \\
\hline KL 4-2 & Kõrge $_{\text {dom }}$ & 0,81 & Kõrge & 0,73 & Kõrge & 0,62 & Kõrge & $-0,30$ & $\begin{array}{l}\text { Kesk- } \\
\text { mine }\end{array}$ \\
\hline KL 4-3 & Kõrge $_{\text {komb }}$ & 0,52 & Kõrge & 1,56 & Kõrge & 0,68 & Kõrge & 1,26 & Kõrge \\
\hline KL 4-4 & Madal $_{\text {komb }}$ & $-1,43$ & Madal & $-1,22$ & Madal & $-1,28$ & Madal & $-1,26$ & Madal \\
\hline KL 4-5 & Madal $_{\text {integr }}$ & 0,81 & Kõrge & $-0,51$ & Madal & 0,76 & Kõrge & 1,15 & Kõrge \\
\hline KL 4-6 & Segaprofil & $-1,10$ & Madal & $-0,01$ & $\begin{array}{l}\text { Kesk- } \\
\text { mine }\end{array}$ & 0,52 & Kõrge & $-0,29$ & $\begin{array}{l}\text { Kesk- } \\
\text { mine }\end{array}$ \\
\hline \multicolumn{10}{|l|}{ 5. klass } \\
\hline KL 5-1 & Madal $_{\text {dom }}$ & 0,00 & Keskmine & $-1,29$ & Madal & $-0,83$ & Madal & $-1,08$ & Madal \\
\hline KL 5-2 & Kõrge $_{\text {dom }}$ & 0,63 & Kõrge & 0,96 & Kõrge & 1,01 & Kõrge & 0,09 & $\begin{array}{l}\text { Kesk- } \\
\text { mine }\end{array}$ \\
\hline KL 5-3 & Kõrge komb & 0,65 & Kõrge & 0,91 & Kõrge & 1,13 & Kõrge & 1,46 & Kõrge \\
\hline KL 5-4 & Madal $_{\text {komb }}$ & $-1,97$ & Madal & $-0,89$ & Madal & $-1,20$ & Madal & $-1,18$ & Madal \\
\hline KL 5-5 & $\begin{array}{l}\text { Kesk- } \\
\text { mine }_{\text {komb }}\end{array}$ & 0,21 & Keskmine & $-0,46$ & $\begin{array}{l}\text { Kesk- } \\
\text { mine }\end{array}$ & 0,47 & $\begin{array}{l}\text { Kesk- } \\
\text { mine }\end{array}$ & 0,47 & $\begin{array}{l}\text { Kesk- } \\
\text { mine }\end{array}$ \\
\hline KL 5-6 & Segaprofill & 0,45 & Keskmine & 0,78 & Kõrge & $-0,59$ & Madal & 0,24 & $\begin{array}{l}\text { Kesk- } \\
\text { mine }\end{array}$ \\
\hline
\end{tabular}

Märkus. TR - tasemerühm; alaindeksi tähendus: dom - domineeriv, komb - kombineeritud, integr - info integreerimine.

Suur osa õpilastest $(37,3 \%)$ paigutus 4. ja 5. klassis profiilirühma, mida iseloomustas kõikide tekstimõistmise komponentide ja verbaalse võimekuse kõrge tase (kõrge-kombineeritud). Suuruselt järgmist rühma iseloomustasid mõlemal aastal keskmisel tasemel verbaalsed võimed ning kõikide tekstimõistmise komponentide kõrge tase (kõrge-domineeriv). 5. klassis suurenes õpilaste arv selles rühmas 20,6\%lt 21,8\%le. Mõlemal aastal leiti ka kaks väikest rühma: madal-domineeriv ja madal-kombineeritud. Erinevus nende vahel seisnes info äratundmise tasemes: madalas- 
domineerivas rühmas oli see keskmine, madalas-kombineeritud rühmas madal; kõikide ülejäänud tekstimõistmise komponentide tasemed nendes rühmades olid madalad. 4. ja 5. klassis leiti ka nn segaprofil, mis paistis silma ülesannete soorituse suure varieeruvusega (madalast kõrgeni), kusjuures õpilaste verbaalsete võimete tase mõlemal aastal oli keskmine. Märkimisväärne arv õpilasi (12,7\%) kuulus 4. klassis profiilirühma, mida iseloomustas vähene info integreerimise oskus ning teiste komponentide kõrge tase (madal-integreeritud). 5. klassis see profilirühm ei avaldunud. Seevastu eristus 5. klassis rühm (15,5\% õpilasi), millele oli omane kõikide tekstimõistmise komponentide keskmine tase (keskmine-kombineeritud).

Et selgitada 4. ja 5. klassis välja profiilirühmad, mis on rohkem või vähem iseloomulikud poistele ja tüdrukutele, kasutati kahe valimi (diskriminandi) KSAd (two-sample CFA; von Eye, 2000). 6 (klaster) $\times 2$ (sugu) analüüsist standardse $\chi^{2}$ testiga selgus, et 4 . klassis oli diskriminatsioonitüübiks madal-domineeriv profiilirühm, kus oli statistiliselt oluliselt vähem tüdrukuid, $p=0,02, f_{o}=14, f_{e}=23,74$, ja rohkem poisse, $p=0,025$, $f_{o}=31, f_{e}=21,26$, kui juhuslikult oodatud. Samasugune analüüside seeria tehti 5. klassis, kus avaldus kaks diskriminatsioonitüüpi: poiste ja tüdrukute jaotus madalas-domineerivas ja kõrges-kombineeritud profiilirühmas oli erinev. Nimelt, kórges-kombineeritud rühmas oli statistiliselt oluliselt vähem poisse, $p=0,036, f_{o}=68, f_{e}=83,15$, ja rohkem tüdrukuid, $p=0,047, f_{o}=108, f_{e}=92,85$. Vastupidine tulemus soolises jaotuses leiti madalas-domineerivas profiilirühmas, kus oli oodatust oluliselt vähem tüdrukuid, $p=0,034, f_{o}=9, f_{e}=16,35$, ja rohkem poisse, $p=0,041, f_{o}=22$, $f_{e}=14,65$.

Muutused õpilaste profiilirühmades. Seejärel uuriti muutusi õpilaste tekstimõistmisoskuses ja verbaalsetes võimetes üleminekul esimesest kooliastmest teise astmesse. Õpilaste jaotuse võrdlemiseks 4. ja 5. klassi profiilirühmades tehti esimest järku KSA Pearsoni $\chi^{2}$ test (Bonferroni teisendusega) (von Eye, 2000). Kahe klassi profiilide vahel leiti viis süstemaatilist muutust (tüüpi) ja kaks harvem esinevat muutust (antitüüpi): $\chi^{2}=236,82, d f=25, p<0,001$ (KSA mooduli järgi). Detailne ülevaade on esitatud tabelis 6 . 
Tabel 6. Tekstimõistmise profilide konfiguratsioonid 4. ja 5. klassis

\begin{tabular}{|c|c|c|c|c|c|c|c|c|c|c|c|c|}
\hline \multirow{2}{*}{$\begin{array}{l}\text { 5. kl } \\
\text { 4. kl }\end{array}$} & \multicolumn{2}{|c|}{ Madal $_{\text {dom }}$} & \multicolumn{2}{|c|}{ Kõrge $_{\text {dom }}$} & \multicolumn{2}{|c|}{ Kõrge $_{\text {komb }}$} & \multicolumn{2}{|c|}{ Madal $_{\text {komb }}$} & \multicolumn{2}{|c|}{ Keskmine $_{\text {komb }}$} & \multicolumn{2}{|c|}{ Segaprofiil } \\
\hline & $f_{o}$ & $f_{e}$ & $f_{o}$ & $f_{e}$ & $f_{o}$ & $f_{e}$ & $f_{o}$ & $f_{e}$ & $f_{o}$ & $f_{e}$ & $f_{o}$ & $f_{e}$ \\
\hline Madal $_{\text {dom }}$ & 10 & 2,96 & 5 & 9,82 & 3 & 16,78 & 2 & 1,81 & 12 & 6,96 & 13 & 6,67 \\
\hline Kõrge $_{\text {dom }}$ & 4 & 6,37 & 37 & 21,17 & 23 & 36,17 & 2 & 3,91 & 17 & 15 & 14 & 14,39 \\
\hline Kõrge $_{\text {komb }}$ & 1 & 11,56 & 32 & 38,41 & 111 & 65,63 & 1 & 7,09 & 16 & 27,22 & 15 & 26,1 \\
\hline Madal $_{\text {komb }}$ & 13 & 2,5 & 4 & 8,29 & 1 & 14,17 & 9 & 1,53 & 4 & 5,88 & 7 & 5,64 \\
\hline Madal $_{\text {integr }}$ & 0 & 3,94 & 18 & 13,09 & 25 & 22,37 & 0 & 2,42 & 8 & 9,28 & 9 & 8,9 \\
\hline $\begin{array}{l}\text { Sega- } \\
\text { profiil }\end{array}$ & 3 & 3,68 & 7 & 12,22 & 13 & 2,88 & 5 & 2,25 & 16 & 8,66 & 12 & 8,31 \\
\hline
\end{tabular}

Märkus. $f_{o}$ - vaadeldud sagedus, $f_{e}$ - oodatud sagedus; poolpaksus kirjas - tüüp, kursiivis antitüüp, olulisusnivoo $p \leq 0,01$ (arvestades Bonferroni teisendust). Alaindeksi tähendus: dom - domineeriv, komb - kombineeritud, integr - info integreerimine.

Leiti kaks tüüpilist stabiilset kõrge tulemuste tasemega profiilikombinatsiooni: 1) kõrge-domineeriv, mida iseloomustas verbaalsete võimete ja kõrge keeleülesannete soorituse keskmine tase, ning 2) kõrge-kombineeri$t u d$, mida iseloomustas kõikide tekstimõistmise komponentide kõrge tase. Tüüpilised stabiilsed profiilid olid ka kaks madala tulemuste tasemega rühma: madal-kombineeritud, kus õpilased said kõikides ülesannetes halvemad tulemused, ja madal-domineeriv rühm, kuhu liigitunud õpilased said kahel aastal info äratundmise ülesandes keskmised tulemused ning teistes ülesannetes halvemad tulemused. Lisaks eristus üks tüüpiline muutuv kombinatsioon 4. klassi madala-kombineeritud ja 5. klassi madaladomineeriva profili vahel. Selle rühma õpilased sooritasid 5. klassis 4. klassiga võrreldes info äratundmise ülesanded paremini.

Lisaks leiti kaks antitüüpi. Üks õpilane liigitus 4. klassis madalassekombineeritud profiliirühma ja liikus sealt 5. klassis kõrgesse-kombineeritud rühma. Kolm õpilast, kes kuulusid 4. klassis madalasse-domineerivasse rühma, liikusid 5. klassis kõrgesse-kombineeritud rühma.

Õpetajate profilid. Eestpoolt nähtus, et klassiõpetajad erinesid oma õpetamistegevuste eelistustelt rühma keskmiste tasemel. Et selgitada välja süstemaatilised erinevused õpetajate õpetamistegevuste profiilides ja nende muutus ajas, leiti esmalt RESIDUE mooduli (Bergman et al., 2003) abil erindid. Kaks õpetajat, kelle mehaanilise õpetamise skoor oli kas erandlikult suur või erandlikult väike, jäeti järgnevatest analüüsidest 
välja. Seejärel sisestati õpetajate andmed andmefaili, märkides iga õpetaja mõõtmistulemused kahel mõõtmishetkel (3. ja 4. klassis), ning neid käsitleti eri juhtumitena. Õpetajat A 3. klassis ja õpetajat A 4. klassis analüüsiti kui õpetajat 1 ja 2, tehti hierarhiline klasteranalüüs.

Kooskõlas teoreetiliste põhjenduste, klastrite homogeensuse (vahemikus $0,38-1,53)$ ja EESS-näitajaga $(63,15)$ valiti viieklastriline lahendus. Sama moodi nagu õpilaste profilide puhul, arvestati ka ópetajate profiilide tõlgendamisel muutuja standardiseeritud skoori: suur $>0,50$; väike $<-0,50$. Valitud viie rühma õpetajatel oli ühe või mitme õpetamistegevuse skoor oluliselt suurem või väiksem kui teiste rühmade õpetajatel (tabelid 7 ja 8 ).

Tabel 7. Õpetamistegevuste profilide kirjeldavad näitajad

\begin{tabular}{l|c|c|c|c|c|c|c|c}
\hline & & & \multicolumn{2}{|c|}{ Mehaaniline } & \multicolumn{2}{c|}{ Mõistmine } & \multicolumn{2}{c}{ Rakendamine } \\
\cline { 2 - 10 } & $N 1$ & $N 2$ & $M$ & $S D$ & $M$ & $S D$ & $M$ & $S D$ \\
\hline Keskmine-kombineeritud & 14 & 14 & 3,41 & 0,23 & 4,38 & 0,23 & 4,46 & 0,24 \\
\hline Rakendamine-mõistmine & 4 & 0 & 2,50 & 0,30 & 4,33 & 0,18 & 4,90 & 0,20 \\
\hline Mehaaniline-mõistmine & 8 & 10 & 3,57 & 0,41 & 4,32 & 0,19 & 3,86 & 0,24 \\
\hline Kõrge-kombineeritud & 1 & 6 & 4,18 & 0,05 & 4,49 & 0,21 & 4,74 & 0,19 \\
\hline Madal-kombineeritud & 7 & 4 & 2,97 & 0,55 & 3,64 & 0,26 & 3,85 & 0,35 \\
\hline
\end{tabular}

Märkus. N1 - õpetajad 3. klassis, N2 - õpetajad 4. klassis.

Tabel 8. Õpetamistegevuste profiilid standardiseeritud skooride järgi

\begin{tabular}{l|r|l|r|l|r|l}
\hline & \multicolumn{2}{|c|}{ Mehaaniline } & \multicolumn{2}{c|}{ Mõistmine } & \multicolumn{2}{c}{ Rakendamine } \\
\cline { 2 - 7 } & \multicolumn{1}{c|}{$\boldsymbol{M}$} & \multicolumn{1}{c|}{$T \boldsymbol{R}$} & $\boldsymbol{M}$ & \multicolumn{1}{c}{$T \boldsymbol{R}$} & $\boldsymbol{M}$ & \multicolumn{1}{c}{$T \boldsymbol{R}$} \\
\hline Keskmine-kombineeritud & 0,13 & Keskmine & 0,44 & Keskmine & 0,20 & Keskmine \\
\hline Rakendamine-mõistmine & $-1,30$ & Madal & 0,29 & Keskmine & 1,10 & Kõrge \\
\hline Mehaaniline-mõistmine & 0,39 & Keskmine & 0,26 & Keskmine & $-1,03$ & Madal \\
\hline Kõrge-kombineeritud & 1,35 & Kõrge & 0,76 & Kõrge & 0,77 & Kõrge \\
\hline Madal-kombineeritud & $-0,56$ & Madal & $-1,75$ & Madal & $-1,05$ & Madal \\
\hline
\end{tabular}

Märkus. TR - tasemerühm. 
Palju õpetajaid (38,9\%) kuulus mõlemal aastal rühma, mida iseloomustas parem mõistmine ning rakendamist ja mehaanilist õppimist toetavate tegevuste kasutamine keskmisel tasemel (keskmine-kombineeritud) (tabel 7). Suuruselt teisele profiilirühmale oli omane keskmisel tasemel mehaaniline õppimine ja mõistmine ning vähene teadmiste rakendamine (mehaaniline-mõistmine). Ligi viiendik õpetajatest (19,4\%) kuulus 3. klassis rühma, mida iseloomustas kõikide õpetamistegevuste vähene eelistus (madal-kombineeritud), kusjuures 4. klassis vähenes õpetajate arv selles rühmas oluliselt $(11,1 \%)$. 3. klassis avaldus rühm, kus oli madal mehaanilise õpetamise tase, keskmine mõistmise arendamise tase ning kõrge teadmiste rakendamise tase (rakendamine-mõistmine). 4. klassis sellist profiili ei leitud. 3. klassis eristus üks õpetaja kõikide õpetamistegevuste, eriti aga mehaanilise õpetamise suure eelistuse poolest (kõrge-kombineeritud), kusjuures 4. klassis suurenes õpetajate arv selles rühmas oluliselt (16,7\%). Kasutades Kruskali-Wallise testi, analüüsiti õpetajate jaotust klastrites vanuse ja töökogemuse järgi - statistiliselt olulisi erinevusi ei leitud.

Muutused õpetajate profilirühmades. Muutuste uurimiseks õpetajate õpetamistegevuste profiilirühmades võeti arvesse järjestikuselt iga õpetaja kaks mõõtmist (3. ja 4. klassi klaster) ning arvutati profiilipaaride kombinatsioonid. Õpetajaid, kes rühmitusid teisel mõõtmishetkel stabiilselt samasse klastrisse kui esimesel hetkel, oli 15 (44,12\%).

Järgnevalt tehti esimest liiki KSA, kasutades binominaalset testi (von Eye, 2000). Õpetajate 3. ja 4. klassi õpetamistegevuste profiilides leiti üks püsiv kombinatsioon ehk tüüp, $\chi^{2}=23,50, d f=12, p=0,024$ (KSA mooduli järgi). Nimelt oli madalas-kombineeritud profiilirühmas oluliselt rohkem õpetajaid kui juhuslikult oodatud, $p=0,009, f_{o}=4, f_{e}=0,82$.

\section{Õpetajate õpetamistegevuste seos õpilaste tekstimõistmisega}

Et selgitada välja seosed õpilaste tekstimõistmise profiilide ja õpetajate õpetamistegevuste profiilide vahel, kasutati esimest järku KSA Pearsoni $\chi^{2}$ testi kahe muutuja kohta: 1) õpilase tekstimõistmise profiil 4. klassis ja õpetaja õpetamistegevuste profiil 3. klassis ning 2) õpilase tekstimõistmise profiil 5. klassis ja õpetaja õpetamistegevuste profill 4. klassis. Võttes arvesse Bonferroni teisendust, eristus esimesel mõõtmishetkel üks tüüpiline kombinatsioon. Kõikide tekstimõistmise komponentide ja verbaalse võimekuse tase oli madal õpilastel (madal-kombineeritud), kelle õpetajaid iseloomustas kõikide õpetamistegevuste vähene eelistus (madal- 
kombineeritud), $\chi^{2}=14,61, p<0,001, f_{o}=15, f_{e}=5$,8. Lisaks avaldus tüüpiline kombinatsioon õpilaste madala-domineeriva profiili ja õpetajate madala-kombineeritud profili vahel, $\chi^{2}=7,42, p=0,006, f_{o}=14, f_{e}=6,86$. Sarnane tüüpiline profiilikombinatsioon õpilaste tekstimõistmise ja õpetajate õpetamistegevuste vahel leiti ka teisel mõõtmishetkel. Kõikides tekstimõistmise ja verbaalse võimekuse ülesannetes saavutasid halvemad tulemused õpilased (madal-kombineeritud), kelle õpetajate eelistus kõikides õpetamistegevustes oli väike (madal-kombineeritud), $\chi^{2}=24,43, p<0,001$, $f_{o}=8, f_{e}=1,65$ (Bonferroni teisendusega).

Lisaks leiti teisel mõõtmishetkel kaks antitüüpi. Ühtegi õpilast, kelle tekstimõistmine ja verbaalne võimekus olid väiksed (madal-kombineeritud), ei esinenud nende õpetajate rühmas, kes kasutasid mehaanilist õpetamist ja mõistmise arendamist keskmisel tasemel (mehaaniline-mõistmine), $\chi^{2}=5,39, p=0,02, f_{o}=0, f_{e}=5,39$. Õpilasi, kelle tekstimõistmisoskus ja verbaalne võimekus olid suured (kombineeritud-kórge), esines harvem, kui võinuks esineda juhuslikult, nende õpetajate profiilirühmas, kes kasutasid kõiki õpetamistegevusi harva (madal-kombineeritud), $\chi^{2}=4,49, p=0,034, f_{o}=7, f_{e}=15,29$.

Et selgitada välja õpetaja õpetamistegevuste mõju õpilaste tekstimõistmise ja verbaalse võimekuse muutusele, analüüsiti koos õpetaja profiliga ainult neid õpilasi, kes eelnevate analüüside põhjal liigitusid tüüpilistesse või ebatüüpilistesse profiilirühmadesse. Õpetajate ja õpilaste profiilide vahel eristusid üks tüüp ja üks antitüüp. Õpilastel, kelle õpetajad kuulusid 4. klassis madalasse-kombineeritud profilirühma, olid stabiilselt nõrgemad tulemused mõlemal aastal kõikides tekstimõistmise komponentides ja verbaalses võimekuses (madal-kombineeritud), $\chi^{2}=30,97, p<0,001$, $f_{o}=6, f_{e}=0,86$ (Bonferroni teisendusega). Õpilasi, kes liikusid 4. klassi madalast-kombineeritud profilirühmast 5. klassi kõrgesse-kombineeritud rühma, esines oluliselt vähem kui juhuslikult oodatud õpetajatel, kelle eelistus kõikide õpetamistegevuste suhtes oli 4 . klassis väike, $\chi^{2}=5,31$, $p=0,02, f_{o}=3, f_{e}=10,45$. Selliste tegevusprofiilidega õpetajatel oli siiski ka õpilasi, kelle tekstimõistmisoskus ja verbaalne võimekus olid väiksed.

\section{Arutelu}

Pikiuurimuses selgitati välja seosed Eesti põhikooli õpilaste tekstimõistmise ja verbaalsete võimete vahel ning klassiõpetajate õpetamistegevuste mõju õpilaste tekstimõistmisele üleminekul esimesest kooliastmest teise astmesse. Rühma- ja indiviidikesksete meetodite abil leiti erinevused nii 
rühmatasandil kui ka õpilaste tekstimõistmise ja õpetajate õpetamistegevuste profiilirühmades. Olulised kombinatsioonid ilmnesid klassiõpetajate tegevuste ja õpilaste tekstimõistmise profilide vahel. Selgus, et õpetajate õpetamistegevuste eelistus seostus õpilaste tekstimõistmisega. Stabiilselt halvemad tulemused tekstimõistmises olid õpilastel, kelle verbaalsed võimed olid väiksemad ning kelle õpetajate eelistus kõikide õpetamistegevuste suhtes püsis väike.

\section{Tekstimõistmine ja soolised erinevused}

Õpilaste tekstimõistmise hindamiseks kasutati emakeele ja verbaalse võimekuse teste, millega mõõdeti info äratundmist ja integreerimist, sõnatähenduse tundmist ja verbaalseid võimeid. Tugevaimad seosed leiti verbaalsete võimete ja sõnatähenduse tundmise vahel. Ka varasemates uurimustes on leitud, et verbaalne võimekus on tähtis tegur sõnavara omandamisel ja sõnade tähenduse eristamisel (Cain \& Oakhill, 2011; Saxton, 2010). Verbaalsed võimed eristavad hästi nii õpiraskustega õpilasi (Männamaa et al., 2008) kui ka erineva akadeemilise edukusega õpilasi (Männamaa \& Kikas, 2010) ning seostuvad omakorda võimega mõista teksti madalamal (nt infot tekstist ära tunda) ja kõrgemal kognitiivsel tasemel (nt loetut analüüsida ja interpreteerida) (Pečjak et al., 2011).

Analüüsides erinevusi poiste ja tüdrukute tekstimõistmises, leiti, et 4. klassis olid tüdrukute keskmised tulemused poistest paremad verbaalsetes võimetes, info integreerimises ja sõnatähenduse tundmises. Ka 5. klassis püsisid nendes ülesannetes erinevused poiste ja tüdrukute vahel. Selline sooline erinevus lugemisoskuses on kooskõlas rahvusvahelise PISA testi, riiklike tasemetööde (Henno et al., 2007; Tire et al., 2010) ning Logani ja Johnsoni uurimuse (2010) tulemustega. Seevastu tekstist info äratundmise ülesannetes ei leitud 4 . klassis poiste ja tüdrukute vahel erinevusi, kuid tüdrukute tulemused olid poistest paremad 5. klassis, kus loetud tekst (valm) oli paari stroofi võrra pikem ja vastusevalikuid rohkem.

\section{Õpetajate õpetamistegevuste eelistused}

Uurides klassiõpetajate õpetamistegevusi 3. ja 4. klassis, leiti, et õpetajate eelistus mõlemas klassis oli väikseim tegevuste korral, mis toetavad mehaanilist õppimist, meeldejätmist ja meenutamist. Sagedamini kasutasid õpetajad mõlemas klassis tegevusi, mis olid suunatud õpilaste mõtlemisoskuse arendamisele, arusaamisele, teadmiste rakendamisele ja seostamisele. See viitab konstruktivistliku õppimiskäsitluse eelistamisele (Schuh, 2004; Shuell, 1996) Eesti algkoolis, mida on märgitud varasemates 
uurimustes (Uibu et al., 2010, 2011). Sellised tulemused erinevad aga Palu ja Kikase (2007) uurimuse tulemustest, kus leiti, et klassiõpetajad eelistavad matemaatika õpetamisel pigem traditsioonilisi meetodeid. See seostub selliste matemaatiliste protseduuride õpetamise eripäraga, mis nõuavad rohkem harjutamist ja treenimist.

Analüüsist ilmnes, et mehaanilise õpetamise eelistus suurenes aastaga. Selline tulemus ei kinnitanud püstitatud hüpoteesi ja lahknes tekstimõistmise arendamise põhimõtetest (Gleason \& Ratner, 2009; Saxton, 2010). Esimeses kooliastmes on emakeeleõpetuse üks eesmärke elementaarse lugemisoskuse ja tekstist info äratundmise arendamine, mis nõuab kordamist ja harjutamist. Teise kooliastme põhiülesanne on tekstimõistmise arendamine, mis eeldab arusaamise, info ülekandmise ja analüüsimise oskuste kujundamist (Gleason \& Ratner, 2009; Mayer, 2002). Kuna rakendamine ja õpitud materjali aktiivne kasutamine on aeganõudev protsess, tunnevad õpetajad vastutust saavutada õpilaste head tulemused ainetestides ning võivad asendada rakendamistegevused mehaanilist õppimist soodustava harjutamisega. Seda, et õpetajad kalduvad ajapuuduse tõttu eelistama harjutamist ja meelespidamise arendamist, on leitud ka varasemates uurimustes (O'Sullivan, 2006; Uibu et al., 2010). Teiste õpetamistegevuste - mõistmise arendamise ja teadmiste rakendamise vahel kahel aastal olulisi erinevusi ei leitud. Selline tulemus on kooskõlas Uibu, Kikase ja Tropi (2011) uurimusega, kus selgus samuti, et õpetajad, kes on orienteeritud arusaamise arendamisele, kasutavad rohkem ka teadmiste rakendamist.

\section{Erinevused õpilaste tekstimõistmise profiilides}

Kasutades indiviidikeskseid meetodeid, leiti kuus õpilaste tekstimõistmise profili. Enam kui kolmandik õpilastest kuulus mõlemal aastal rühma, mida iseloomustas kõikide ülesannete kõrge soorituse tase. Need õpilased lahendasid edukalt verbaalse võimekuse, sõnatähenduse tundmise ja tekstimõistmise ülesanded. Suuruselt teise rühma liigitus üle 1/5 õpilastest, kes said head tulemused sõnavara ja tekstimõistmise ülesannetes, kuid nende verbaalsed võimed oli keskmisel tasemel. 5. klassis suurenes õpilaste arv selles profiilirühmas. Nagu näitavad ka varasemad tulemused (Männamaa \& Kikas, 2010), pole emakeeletestis heade tulemuste saavutamise eeldus alati verbaalsete võimete kõrge tase. Edukad võivad olla ka keskmise verbaalse võimekusega õpilased ja akadeemilist edukust ei määra alati vaimsed võimed, vaid ka muud tegurid (sh testimiseks kasutatud mõõtevahendid, motivatsioon, õpetamistegevused). 
Lisaks eristus kaks väiksemat rühma, kuhu mõlemal aastal liigitus alla $10 \%$ õpilastest. Esimesse rühma kuulusid õpilased, kelle kõikide ülesannete soorituse tase oli madal. Teist rühma iseloomustas info äratundmise keskmine tase ja teiste ülesannete madal tase. Selles rühmas domineerisid mõlemal aastal poisid. Info märkamine ja äratundmine nõuavad eelkõige tähelepanu ja meelespidamist (Krathwohl, 2002; Mayer, 2002). Keerulisemate ülesannete lahendamine, milleks läheb tarvis laiemat sõnavara, head semantilist pädevust, info töötlemise ja integreerimise oskust, võib aga arenguliste iseärasuste tõttu osutuda poistele raskeks (Logan \& Johnson, 2010; Saxton, 2010). Mõlemas klassis ilmnesid ka nn segaprofilid. Kuigi neid rühmi iseloomustas sõnatähenduse ja lugemisülesannete soorituse varieeruv tase, oli õpilaste verbaalne võimekus vaatlusalustes rühmades mõlemal aastal keskmisel tasemel.

Võrreldes õpilaste tekstimõistmise profiile kahel aastal, leiti, et 4. klassis oli peaaegu $13 \%$ õpilastest halvad tulemused info integreerimise ülesannetes, kuigi teiste ülesannete soorituse tase oli neil kõrge. 5. klassis sellist profilirühma ei ilmnenud. Kuna info integreerimine nõuab head analüüsi- ja järeldamisoskust, siis võib esimeses kooliastmes olla õpilasi, kellel need oskused ei ole veel piisavalt arenenud (Gleason \& Ratner, 2009). Puudulikud oskused põhjustavad vigu tekstipõhise info integreerimises (Schroeder, 2011). Vähese integreerimisoskusega õpilaste profiilirühma puudumist 5. klassis võib seletada sellega, et kooskõlas õppekava nõudmistega on 5. klassis õpilastel rohkem kogemusi info integreerimist nõudvate ülesannete lahendamisel ning seda tüüpi ülesannetele pööravad õpetajad õpetamisel enam tähelepanu. Ent 5. klassis leiti profiilirühm (keskmine-kombineeritud, 15,5\% õpilastest), mis ei avaldunud 4. klassis. Põhjuseks võib pidada arengulisi muutusi tekstimõistmise komponentides ja verbaalses võimekuses. Akadeemiliste tulemuste ja võimete dünaamilist hindamist on ka varem oluliseks peetud (Kempe et al., 2011; Kim et al., 2009; Mooij \& Driessen, 2008; Männamaa \& Kikas, 2010; Phillips et al., 2002), sest muutused ajas võivad olla mitmesuunalised ja probleemid selguda hiljem (Leach et al., 2003).

Analüüsides muutust õpilaste tekstimõistmise profiilides, leiti kaks stabiilselt paremate tulemustega kombinatsiooni: kõikide ülesannete soorituse kõrge tase; keeleülesannete soorituse kõrge tase ja verbaalse võimekuse keskmine tase. Leiti ka kaks stabiilselt halvemate tulemustega kombinatsiooni: kõikide ülesannete soorituse madal tase või info äratundmise soorituse keskmine tase ja teiste ülesannete soorituse madal tase. Seega, nii kehvema kui ka hea lugemisoskusega algklassiõpilastel oli suurem tõenäosus kuuluda samasse tasemerühma ka järgmisel aastal. 
Kuigi tekstimõistmise stabiilsust on kinnitanud ka teised uurijad (Juel, 1988; Kim et al., 2009; Phillips et al., 2002), ei iseloomusta tulemuste stabiilsus kõiki õpilasi. Individuaalseid erinevusi stabiilsuses ja muutustes võib leida nii õpilaste võimete tasemes kui ka tekstimõistmise erinevate komponentide ja nende seoste vahel.

Õpilaste tekstimõistmise profiilides avaldus lisaks üks tüüpiline muutuv kombinatsioon. Õpilastel, kellel 4. klassis oli kõikide ülesannete soorituse tase madal, paranesid 5. klassis tulemused info äratundmise ülesandes. Ka varem on leitud, et keskmise või keskmisest väiksema võimekusega õpilaste tulemused emakeeles võivad ajas paraneda (Mooij \& Driessen, 2008; Männamaa \& Kikas, 2010). Seejuures on oluline toetada neid õpilasi sobivate lugemisstrateegiate ja õpetamistegevustega (Foorman et al., 2006). Ent suured hüpped tekstimõistmises üheaastase intervalliga olid siinses uurimuses harvad. Ebatüüpiline oli liikumine kõikide ülesannete madala tasemega profiilirühmast kõikide ülesannete kõrge tasemega rühma.

\section{Erinevused õpetajate õpetamistegevuste profiilides}

Analüüsides õpetajate õpetamistegevuste profiile, leiti viis profiilirühma. Suurimat neist iseloomustas suhteliselt kõrgel tasemel mõistmise arendamine ning keskmisel tasemel rakendamist ja mehaanilist õppimist toetavate tegevuste eelistus. Sellesse rühma kuulunud õpetajad väärtustasid enim õpilaste mõtlemis-, arusaamis- ja tõlgendamisoskuse arendamist ning keskmisel tasemel info meeldejätmist ja teadmiste rakendamist. Suuruselt teine rühm õpetajaid kasutas mõistmist ja mehaanilist õppimist toetavaid tegevusi keskmisel tasemel, kuid rakendustegevuste tase oli nende puhul madal. Sellise profiiliga õpetajad olid suunatud rohkem faktiteadmiste ja arusaamise arendamisele ning soodustasid vähem teadmiste rakendamist. Kuigi tekstimõistmise puhul on oluline arendada mõtlemist ja arusaamist (Krathwohl, 2002; Mayer, 2002), eeldab loetu mõistmine sõnavara, sõnatähenduste ja faktiteadmiste omandamist ning uute teadmiste seostamist igapäevaeluga (Pečjak et al., 2011). Samas eristus üks väiksem profiilirühm, kus õpetajate kõikide tegevuste eelistus oli väike. Et toetada õpilaste kognitiivsete oskuste, sh tekstimõistmise arengut, tuleks aga kombineerida erinevaid tegevusi ja strateegiaid (Perry et al., 2007; Uibu et al., 2010).

3. klassis avaldus väike rühm õpetajaid, kes erinesid teistest oma õpetamistegevuste suure variatiivsuse poolest. Nemad kasutasid kõige rohkem rakendamist toetavaid tegevusi ja kõige vähem mehaanilist 
ópetamist. Rakendustegevused on vajalikud õpitud materjali aktiivsel kasutamisel (Krashen, 1982; Krathwohl, 2002). Seevastu elementaarse lugemisoskuse omandamine nõuab harjutamist ja kinnistamist. Kui õpilased on saavutanud 4. klassi alguseks hea elementaarse lugemisoskuse, siis on harjutamise ja tekstist info otsimise asemel olulisem õppida teadmisi integreerima ja rakendama, sh seostada infot teistes ainetes õpituga (Gleason \& Ratner, 2009).

Lisaks leiti veel üks rühm õpetajaid, kes kasutasid kõiki õpetamistegevusi kõrgel tasemel. 3. klassis kuulus sellesse rühma üks õpetaja, kelle õpilaste tulemused olid head kas kõikides ülesannetes või varieerusid ülesannete arvestuses (nn segaprofiil). 4. klassis kasvas õpetajate arv selles rühmas oluliselt (6 õpetajat). Kuna teises kooliastmes suureneb uute teadmiste hulk, suurenevad ka nõudmised õpilaste tekstimõistmisele. Et õpilane omandaks uue info, tuleks kasutada mõistmist ja seostamist toetavaid tegevusi, et teadmised paigutuksid terviksüsteemi (Saxton, 2010; Schuh, 2004).

Võrreldes õpetajate profiilirühmi kahel järjestikusel aastal, ootasime rühma keskmisest tasemest suuremaid muutusi. Selgus, et $44 \%$ õpetajatest rühmitus mõlemal aastal samasse profiilirühma. See kinnitab, et õpetaja käitumine klassiruumis on üsna stabiilne, sest see on mõjutatud uskumustest, mis on ajas suhteliselt püsivad (Woolfolk Hoy, Davis, \& Pape, 2006; Uibu et al., 2010). Lisaks ilmnes üks oluline profiilikombinatsioon: oodatust märksa rohkem õpetajaid kasutas kõiki õpetamistegevusi mõlemal aastal vähe. Need õpetajad ei lähtunud õpetamistegevuste valikul õpilaste üldisest kognitiivsest arengust ega individuaalsest eripärast (Gleason \& Ratner, 2009).

\section{Õpetamistegevuste mõju õpilaste tekstimõistmisele}

Järgnevalt hinnati, kas erineva õpetamistegevuste profiiliga õpetajate õpilased erinevad tekstimõistmise ja verbaalsete võimete taseme poolest. Selgus, et need 4. klassi õpilased, kelle õpetajate eelistus kõikide õpetamistegevuste suhtes oli väike, saavutasid kehvi tulemusi nii tekstimõistmise kui ka verbaalse võimekuse testides või oli nende tekstist info äratundmine keskmisel tasemel ning ülejäänud ülesannete sooritus madalal tasemel. Sarnane tulemus leiti ka 5. klassis: ülesandeid tegid halvemini õpilased, kelle õpetajate eelistus kõikide õpetamistegevuste suhtes oli väike. Samuti oli sellise profiiliga õpetajatel 5. klassis vähem õpilasi, kes paistsid silma oma hea tekstimõistmise ja verbaalse võimekusega. Varem on leitud (Foorman et al., 2006; Schuh, 2004; Uibu et al., 2010), et õpilaste 
kognitiivse arengu toetamiseks tuleks ühendada erinevad tegevused, nt mehaaniline õpetamine, mõistmise arendamine ja praktilised tegevused.

Lisaks, nende õpetajate rühmas, kes kasutasid 4. klassis mehaanilist õpetamist ja mõistmise arendamist keskmisel tasemel, ei olnud ühtegi õpilast, kelle tekstimõistmise ja verbaalse võimekuse tase oleks olnud madal. Seega suurendades õpetamistegevuste kasutamise sagedust, saab parandada ka õpilaste tekstimõistmisoskust. Samas ei saa väita, et õpetajate õpetamistegevused määravad õpilaste tekstimõistmise taseme. Õpetamistegevuste ja õpilaste tekstimõistmise vahel võib olla retsiprookne põhjuslikkus. Õpetajad võivad valida õpilaste väiksemate kognitiivsete oskuste arendamisele suunatud õpetamistegevusi just seetõttu, et õpilaste oskused ja üldised võimed on väiksemad (Krashen, 1982; Saxton, 2010; Schuh, 2004).

Analüüsides õpetamistegevuste seoseid õpilaste tekstimõistmise arenguga, leiti, et stabiilselt halvemad tulemused tekstimõistmise ja vaimse võimekuse testides olid õpilastel, kelle õpetajate eelistus kõikide tegevuste suhtes oli väike. Sellise profiiliga ópetajate klassis oli ka juhuslikult oodatust oluliselt vähem õpilasi, kelle tase paranes aastaga madalast kõrgeks. Niisiis, muutused õpilaste tekstimõistmises eeldaksid õpetajalt tegevuste varieerimist ja kohandamist laste kognitiivse arengutaseme järgi.

\section{Piirangud ja järeldused}

Uurimusel olid mõned piirangud, mida peab arvestama tulemuste üldistamisel. Esiteks, õpilaste tekstimõistmist hinnati ainult narratiivse tekstiga (valm), kuid kasutada võib ka teisi tekstiliike, nt populaarteaduslikke, tarbetekste (Eason, Goldberg, Young, Geist, \& Cutting, 2012). Teiseks, uurimuses ei hinnatud selliseid tekstimõistmist mõjutavaid tegureid nagu eelteadmised, lugemise täpsus, enesehinnang. Kolmandaks, tekstimõistmist ja verbaalseid võimeid hinnati aastase intervalliga, mis võib olla liiga lühike aeg kõigi muutuste avaldumiseks õpilaste kognitiivsetes võimetes, sh tekstimõistmises. Neljandaks, tekstimõistmise ja verbaalsete võimete muutuses võib oma osa olla teistel kognitiivsetel protsessidel (nt töömälul, tähelepanul) või mittekognitiivsetel teguritel (nt motivatsioonil).

Ometi võimaldab uurimus oma esindusliku valimi, pikiuurimusliku laadi ja õpetajate õpetamistegevuste kaasamise tõttu teha järeldusi õpilaste tekstimõistmise komponentide ja nende muutuse kohta ning anda soovitusi esimese-teise kooliastme õpilaste lugemisoskuse arendamiseks.

1. Õpilased, kes on verbaalselt võimekamad, saavutavad üldiselt paremaid tulemusi tekstimõistmises ja sõnatähenduse tundmises. Seepärast 
peaks õpetaja toetama õppeprotsessis just väiksema verbaalse võimekusega õpilasi, et nende sõnatähenduse ja teksti mõistmise oskused ei jääks eakaaslastega võrreldes oluliselt madalamale tasemele.

2. Kuna õpilaste sõnatähenduse tundmine seostus tugevamini verbaalse võimekusega kui tekstist info äratundmise ja selle integreerimise oskusega, siis võiks koostada selliseid tekstimõistmise ülesandeid, mis toetavad erinevate tekstimõistmise komponentide seostamist.

3. Tüdrukute verbaalsed võimed, info integreerimise oskus ja sõnatähenduse tundmine olid mõlemal aastal oluliselt paremad kui poistel. Vaja on pöörata tähelepanu poiste oskustele, et arendada nende tekstimõistmisoskust kompleksselt. Sel eesmärgil võiksid õpetajad kombineerida erinevaid õpetamistegevusi.

4. Nii parema kui ka kehvema tekstimõistmisoskuse ja verbaalse võimekusega õpilastel oli suurem tõenäosus püsida samas tasemerühmas nii 4. kui ka 5. klassis. Suured muutused õpilaste tekstimõistmises aastase intervalliga olid ebatüüpilised. Samas, tekstimõistmise areng ei ole ühesuunaline protsess: kõikide õpilaste tulemused ei pruugi ajas paraneda; on õpilasi, kelle tulemused halvenevad, mistõttu on põhjendatud akadeemilise edukuse kõrval nii tekstimõistmise komponentide kui ka verbaalsete võimete hindamine erineval ajal - meie tulemuste näitel vähemalt aastase intervalliga.

5. Õpetajatel, kes rakendasid vähem kõiki õpetamistegevusi, oli rohkem selliseid õpilasi, kes said kehvemad tulemused tekstimõistmise ja verbaalsete võimete testides. Seepärast võib erinevate õpetamistegevuste osatähtsuse suurendamine parandada õpilaste tekstimõistmisoskust.

6. Stabiilselt kehvemad tulemused tekstimõistmises olid õpilastel, kelle õpetajate eelistus erinevate õpetamistegevuste suhtes püsis väike. Õpilaste tekstimõistmisoskuste arendamiseks on oluline varieerida õpetamistegevusi, võttes arvesse õpilaste kognitiivset arengut.

\section{Tänusõnad}

Uurimust ja artikli kirjutamist on toetanud haridus- ja teadusministeerium (grant 3-2/TA5966), ESFi programm Eduko (projekt 1.2.0302.09-004) ja Eesti Teadusagentuur (grant IUT03-03). Palju tänu Kristiina Treialile SLEIPNERi programmi kasutamisega seotud nõuannete eest. 


\section{Kasutatud kirjandus}

Bergman, L. R., Magnusson, D., \& El-Khouri, B. M. (2003). Studying individual development in an interindividual context. Mahwah, London: Lawrence Erlbaum Associates.

Berninger, V. W., Abbott, R. D., Vermeulen, K., \& Fulton, C. M. (2006). Paths to reading comprehension in at-risk second-grade readers. Journal of Learning Disabilities, 39(4), 334-351. http://dx.doi.org/10.1177/00222194060390040701

Broek, P. van den, \& Espin, C. A. (2012). Connecting cognitive theory and assessment: Measuring individual differences in reading comprehension. School Psychology Review, 41(3), 315-325.

Cain, K., \& Oakhill, J. (2006). Profiles of children with specific reading comprehension difficulties. British Journal of Educational Psychology, 76(4), 683-696. http://dx.doi.org/10.1348/000709905X67610

Cain, K., \& Oakhill, J. (2007). Reading comprehension difficulties: Correlates, causes, and consequences. In K. Cain \& J. Oakhill (Eds.), Children's comprehension problems in oral and written language: A cognitive perspective (pp. 41-76). New York, London: The Guilford Press.

Cain, K., \& Oakhill, J. (2011). Matthew effects in young readers: Reading comprehension and reading experience aid vocabulary development. Journal of Learning Disabilities, 44(5), 431-443. http://dx.doi.org/10.1177/0022219411410042

Carretti, B., Cornoldi, C., De Beni, R., \& Romano, M. (2005). Updating in working memory: A comparison of good and poor comprehenders. Journal of Experimental Child Psychology, 91(1), 45-66. http://dx.doi.org/10.1016/j.jecp.2005.01.005

Catts, H. W., \& Ellis Weismer, S. (2006). Language deficits in poor comprehenders: A case for the simple view of reading. Journal of Speech, Language, and Hearing Research, 49(2), 278-293. http://dx.doi.org/10.1044/1092-4388(2006/023)

Chomsky, N. (1964). The development of grammar in child language: Formal discussion. Monographs of the Society for Research in Child Development, 29(1), 35-42. http://dx.doi.org/10.2307/1165753

Cohen, L., Manion, L., \& Morrison, K. (2007). Research methods in education (6th ed.). London, New York: Routledge.

Connor, C. M., \& Al'Otaiba, S. (2008). Literacy. USA: Elsevier Inc.

Cutting, L. E., \& Scarborough, H. S. (2006). Prediction of reading comprehension: Relative contributions of word recognition, language proficiency, and other cognitive skills can depend on how comprehension is measured. Scientific Studies of Reading, 10(3), 277-299. http://dx.doi.org/10.1207/s1532799xssr1003_5

Eason, S. H., Goldberg, L. F., Young, K. M., Geist, M. C., \& Cutting, L. E. (2012). Reader-text interactions: How differential text and question types influence cognitive skills needed for reading comprehension. Journal of Educational Psychology, 104(3), 515-528. http://dx.doi.org/10.1037/a0027182

Echols, L. D., West, R. F., Stanovich, K. E., \& Zehr, K. S. (1996). Using children's literacy activities to predict growth in verbal cognitive skills: A longitudinal investigation. Journal of Educational Psychology, 88(2), 296-304.

http://dx.doi.org/10.1037/0022-0663.88.2.296 
Fisher, D., Frey, N., \& Lapp, D. (2008). Shared readings: Modeling comprehension, vocabulary, text structures, and text features for older readers. The Reading Teacher, 61(7), 548-556. http://dx.doi.org/10.1598/RT.61.7.4

Foorman, B. R., Schatschneider, C., Eakin, M. N., Flecher, J. M., Moats, L. C., \& Francis, D. J. (2006). The impact of instructional practices in Grades 1 and 2 on reading and spelling achievement in high poverty schools. Contemporary Educational Psychology, 31(1), 1-29. http://dx.doi.org/10.1016/j.cedpsych.2004.11.003

Gleason, J. B., \& Ratner, N. B. (2009). The development of language (7th ed.). Boston: Allyn \& Bacon.

Goff, D. A., Pratt, C., \& Ong, B. (2005). The relations between children's reading comprehension, working memory, language skills and components of reading decoding in a normal sample. Reading and Writing, 18(7-9), 583-616. http://dx.doi.org/10.1007/s11145-004-7109-0

Henno, I., Tire, G., Lepmann, T., Reiska, P., \& Ehala, M. (2007). Ülevaade rahvusvahelise õpilaste õpitulemuslikkuse hindamise programmi PISA 2006 tulemustest. Külastatud aadressil http://uuringud.ekk.edu.ee/fileadmin/user_upload/ documents/PISA_16pparuanne_041207.pdf.

Hennoste, M. (2012). Eesti keele 3. klassi üleriigilise tasemetöö tulemused 2012. Külastatud aadressil http://www.innove.ee/UserFiles/Tasemet\%C3\%B6\%C3\%B6d/2012/ Eesti\%20keele\%203\%20\%20klassi\%20tasemetoo\%20tulemused\%202012.pdf.

Hollingsworth, P. M., \& Hoover, K. H. (1991). Elementary teaching methods (4th ed.). Boston: Allyn \& Bacon.

Johnson-Glenberg, M. S. (2000). Training reading comprehension in adequate decoders/poor comprehenders: Verbal versus visual strategies. Journal of Educational Psychology, 92(4), 772-782. http://dx.doi.org/10.1037/0022-0663.92.4.772

Jongejan, W., Verhoeven, L., \& Siegel, L. S. (2007). Predictors of reading and spelling abilities in first- and second-language learners. Journal of Educational Psychology, 99(4), 835-851. http://dx.doi.org/10.1037/0022-0663.99.4.835

Juel, C. (1988). Learning to read and write: A longitudinal study of 54 children from first through fourth grades. Journal of Educational Psychology, 80(4), 437-447. http://dx.doi.org/10.1037/0022-0663.80.4.437

Kempe, C., Eriksson-Gustavsson, A.-L., \& Samuelsson, S. (2011). Are there any Matthew effects in literacy and cognitive development? Scandinavian Journal of Educational Research, 55(2), 181-196. http://dx.doi.org/10.1080/00313831.2011.554699

Kim, J. S., Samson, J. F., Fitzgerald, R., \& Hartry, A. (2009). A randomized experiment of a mixed-methods literacy intervention for struggling readers in grades 4-6: Effects on word reading efficiency, reading comprehension and vocabulary, and oral reading fluency. Reading and Writing, 23(9), 1109-1129. http://dx.doi.org/10.1007/s11145-009-9198-2

Kirby, J. R., Deacon, S. H., Bowers, P. N., Izenberg, L., Wade-Woolley, L., \& Parrila, R. (2012). Children's morphological awareness and reading ability. Reading and Writing, 25(2), 389-410. http://dx.doi.org/10.1007/s11145-010-9276-5

Krashen, S. D. (1982). Principles and practice in second language acquisition. Oxford etc.: Pergamon Press. 
Krathwohl, D. R. (2002). A revision of Bloom's taxonomy: An overview. Theory into Practice, 41(4), 212-218. http://dx.doi.org/10.1207/s15430421tip4104_2

Kyriacides, L., Campbell, R. J., \& Christofidou, E. (2002). Generating criteria for measuring teacher effectiveness through a self-evaluation approach: A complementary way of measuring teacher effectiveness. School Effectiveness and School Improvement, 13(3), 291-325. http://dx.doi.org/10.1076/sesi.13.3.291.3426

Leach, J. M., Scarborough, H. S., \& Rescorla, L. (2003). Late-emerging reading disabilities. Journal of Educational Psychology, 95(2), 211-224. http://dx.doi.org/10.1037/0022-0663.95.2.211

Lenneberg, E. H. (1967). Biological foundations of language. New York etc.: Wiley.

Lervåg, A., \& Aukrust, V. G. (2010). Vocabulary knowledge is a critical determinant of the difference in reading comprehension growth between first and second language learners. Journal of Child Psychology \& Psychiatry, 51(5), 612-620. http://dx.doi.org/10.1111/j.1469-7610.2009.02185.x

Logan, S., \& Johnston, R. (2010). Investigating gender differences in reading. Educational Review, 62(2), 175-187. http://dx.doi.org/10.1080/00131911003637006

Mayer, R. E. (2002). Rote versus meaningful learning. Theory into Practice, 41(4), 226-232. http://dx.doi.org/10.1207/s15430421tip4104_4

McKeown, M., \& Beck, I. L. (2004). Direct and rich vocabulary instruction. In J. F. Baumann \& E. J. Kame'enui (Eds.), Vocabulary instruction (pp. 13-27). New York: Guilford.

Mooij, T., \& Driessen, G. (2008). Differential ability and attainment in language and arithmetic of Dutch primary school pupils. British Journal of Psychological Society, 78(3), 491-506.

Männamaa, M., \& Kikas, E. (2010). Cognitive profiles and their stability in different academic performance groups for math and language. In A. Toomela (Ed.), Systemic person-oriented study of child development in early primary school (pp 95-131). Frankfurt: Peter Lang.

Männamaa, M., Kikas, E., \& Raidvee, A. (2008). The effect of testing condition on word guessing in elementary school children. Journal of Psychoeducational Assessment, 26(1), 16-26. http://dx.doi.org/10.1177/0734282907300776

Nation, K., Cocksey, J., Taylor, J. S., \& Bishop, D. V. (2010). A longitudinal investigation of early reading and language skills in children with poor reading comprehension. Journal of Child Psychology \& Psychiatry, 51(9), 1031-1039. http://dx.doi.org/10.1111/j.1469-7610.2010.02254.x

O'Sullivan, M. C. (2006). Teaching large classes: The international evidence and a discussion of some good practice in Ugandan primary schools. International Journal of Educational Development, 26(1), 24-37. http://dx.doi.org/10.1016/j.ijedudev.2005.05.010

Palu, A., \& Kikas, E. (2007). Primary school teachers' beliefs about teaching mathematics. Nordic Studies in Mathematics Education, 12(1), 5-21.

Pečjak, S., Podlesek, A., \& Pirc, T. (2011). Model of reading comprehension for $5^{\text {th }}$ grade students. Studia Psychologica, 53(1), 53-67.

Perry, K. E., Donohue, K. M., \& Weinstein, R. S. (2007). Teaching practices and the promotion of achievement and adjustment in first grade. Journal of School Psychology, 45(3), 269-292. http://dx.doi.org/10.1016/j.jsp.2007.02.005 
Phillips, L. M., Norris, S. P., Osmond, W. C., \& Maynard, A. M. (2002). Relative reading achievement: A longitudinal study of 187 children from first through sixth grades. Journal of Educational Psychology, 94(1), 3-13.

http://dx.doi.org/10.1037/0022-0663.94.1.3

Primrose, A. F., Fuller, M., \& Littledyke, M. (2000). Verbal reasoning test scores and their stability over time. Educational Research, 42(2), 167-174.

http://dx.doi.org/10.1080/001318800363809

Reynolds, M. R., \& Turek, J. J. (2012). A dynamic developmental link between verbal comprehension-knowledge (Gc) and reading comprehension: Verbal comprehension-knowledge drives positive change in reading comprehension. Journal of School Psychology, 50(6), 841-863. http://dx.doi.org/10.1016/j.jsp.2012.07.002

Saxton, M. (2010). Child language: Acquisition and development. London etc.: Sage Publication Ltd.

Schepens, A., Aeltermann, A., \& Van Keer, H. (2007). Studying learning processes of student teachers with stimulated recall interviews through changes in interactive cognitions. Teaching and Teacher Education, 23(4), 457-472. http://dx.doi.org/10.1016/j.tate.2006.12.014

Schroeder, S. (2011). What readers have to do: Effects of students' verbal ability and reading time components on comprehension with and without text availability. Journal of Educational Psychology, 103(4), 877-896. http://dx.doi.org/10.1037/a0023731

Schuh, K. L. (2004). Learner-centered principles in teacher-centered practices? Teaching and Teacher Education, 20(8), 833-846.

http://dx.doi.org/10.1016/j.tate.2004.09.008

Shuell, T. J. (1996). Teaching and learning in a classroom context. In D. C. Berliner \& R. C. Calfee (Eds.), Handbook of Educational Psychology (pp. 726-764). New York: Macmillan.

Sinka, M. (2008). 6. klassi eesti keele 2008. aasta riikliku tasemetöö analüüs. Külastatud aadressil http://www.ekk.edu.ee/vvfiles/0/6_\%20klassi_eesti_\%20keele_\%20tasemet_366_366\%202008\%20anal_374_374sx.pdf.

Soodla, P., \& Kikas, E. (2010). Teachers' judgment of students' reading difficulties and factors related to its accuracy. In A. Toomela (Ed.), Systemic person-oriented study of child development in early primary school (pp. 73-94). Frankfurt: Peter Lang.

Tire, G., Puksand, H., Henno, I., \& Lepmann, T. (2010). PISA 2009 - Eesti tulemused. Eesti 15-aastaste õpilaste teadmised ja oskused funktsionaalses lugemises, matemaatikas ja loodusteadustes. Tallinn: Haridus- ja Teadusministeerium. Külastatud aadressil http://www.ekk.edu.ee/vvfiles/0/PISA_2009_Eesti.pdf.

Toomela, A. (Ed.) (2010). Systemic person-oriented study of child development in early primary school. Frankfurt am Main etc.: Peter Lang.

Uibu, K., Kikas, E., \& Tropp, K. (2010). Teaching practices, their dynamics, associations with self-reported knowledge and students' language achievement. In A. Toomela (Ed.), Systematic person-oriented study of child development in early primary school (pp. 47-71). Frankfurt am Main etc.: Peter Lang.

Uibu, K., Kikas, E., \& Tropp, K. (2011). Instructional approaches: Differences between kindergarten and primary school teachers. COMPARE: A Journal of Comparative and International Education, 41(1), 91-111.

http://dx.doi.org/10.1080/03057925.2010.481121 
Uibu, K., \& Tropp, K. (2013). Longitudinal study of the development of language competence among the Estonian 4th and 5th grade students. In J. Mikk, P. Luik, \& M. Veisson (Eds.), Change in teaching and learning. Estonian studies in education (Vol. 5, pp. 45-63). Frankfurt am Main: Peter Lang.

Vabariigi Valitsus (2007). Põhikooli ja gümnaasiumi riiklik õppekava. Riigi Teataja I 2007, 40, 294. Külastatud aadressil https://www.riigiteataja.ee/ert/act.jsp?id=802290.

Von Eye, A. (2000). Introduction to configural frequency analysis. The search for types and antitypes in cross-classifications. Cambridge: Cambridge University Press.

Watson, C. S., Kidd, G. R., Horner, D. G., Connell, P. J., Lowther, A., Eddins, D. A., Kruger, G., Goss, D. A., Rainey, B. B., Gospel, M. D., \& Watson, B. U. (2003). Sensory, cognitive, and linguistic factors in the early academic performance of elementary school children: The Benton-IU project. Journal of Learning Disabilities, 36(2), 165-197. http://dx.doi.org/10.1177/002221940303600209

Woolfolk Hoy, A., Davis, H., \& Pape, S. J. (2006). Teacher knowledge and beliefs. In P. A. Alexander \& P. H. Winne (Eds.), Handbook of educational psychology (pp. 715-732). London: Lawrence Erlbaum Associates. 


\title{
Teaching practices and text comprehension in students during the transition from the first to second stage of school
}

\author{
Krista Uibua ${ }^{\text {al }}$, Mairi Männamaa ${ }^{\text {bc }}$ \\ ${ }^{a}$ University of Tartu, Institute of Educational Science \\ ${ }^{b}$ Tallinn University, Institute of Psychology \\ ${ }^{c}$ Children's Clinic of Tartu University Hospital
}

\section{Summary}

\section{Introduction}

Children acquire their elementary reading and text comprehension skills at primary school. Good reading skills is not only essential in the context of language sub-skills, but it is the basis of academic success in all subjects (Cain \& Oakhill, 2007). According to the OECD results in PISA 2009 (Programme for International Student Assessment), Estonian students came 10th among OECD countries in reading comprehension skills and even higher, fifth, among European countries (Tire et al., 2010).

Despite these high results in international studies, there are still students who have difficulties with age-appropriate text comprehension (Henno et al., 2007; Soodla \& Kikas, 2010; Tire et al., 2010). Some children who struggled with text comprehension had satisfactory or even good reading skills (Lervåg \& Aukrust, 2010). Among poor performers there are children with very different abilities (Cain \& Oakhill, 2006), and their prevalence is higher in the case of low abilities (Reynolds \& Turek, 2012). In addition to varying abilities, differences in text comprehension have also been found between boys and girls, mostly in favour of girls (Logan \& Johnston, 2010; Tire et al., 2010).

There is no common agreement on which abilities and skills are most essential in text comprehension. Verbal skill has been considered a good indicator of text comprehension (Berninger et al., 2006; Echols et al., 1996; Pečjak et al., 2011). Vocabulary and previous knowledge play an important role in text comprehension (Broek \& Espin, 2012; McKeown \& Beck, 2004). What makes a text easier to comprehend is some knowledge of semantics, syntactic and grammatical constructions (Cain \& Oakhill,

1 Institute of Education, Faculty of Social Sciences and Education, University of Tartu, Salme 1a, 50103 Tartu, Estonia; krista.uibu@ut.ee 
2007, 2011) and the skill to process and extrapolate information (Krashen, 1982; Lenneberg, 1967).

Previous research has shown contradictory results - there are references to the persistence of text comprehension problems (Kim et al., 2009; Nation et al., 2010), but also to their change with the times (Mooij \& Driessen, 2008; Männamaa \& Kikas, 2010; Phillips et al., 2002). At the same time, a reliable profile of skills and abilities that predict difficulties with text comprehension has not been found (Watson et al., 2003).

Teacher's practices play a significant role in shaping student reading skills (Foorman et al., 2006; Perry et al., 2007). As the purpose of reading is somewhat different in each school stage - in primary school the focus is on acquiring the basic vocabulary and elementary reading skill, in basic school on comprehending the text and getting information in various subject areas - it is important to use different practices to develop the students' reading skills (Gleason \& Ratner, 2009).

The aim of the current longitudinal study was to examine the development of student reading comprehension and verbal abilities at the first and second stage of basic school (grades 1-6) and to evaluate the influence of teaching practices on this development. The following six goals were set for the study.

1. To analyse the relationships between text comprehension tasks and verbal skills.

2. To determine the extent to which reading comprehension varies between boys and girls.

3. To assess primary school teachers' preferences in regard to teaching practices.

4. To determine the stability and change in student reading comprehension profiles over a year.

5. To investigate the stability and change in the subgroups of teachers with different teaching practice profiles.

6. To analyse the impact of teaching practices on student reading comprehension performance.

\section{Method}

This study is part of a larger research project (Toomela, 2010), where six hundred and nine primary school students and their teachers $(N=36)$ participated in the longitudinal study. All students studied in regular classes according to the Estonian National Curriculum for Basic School and Upper Secondary School (Vabariigi Valitsus, 2007). The students' 
reading comprehension was assessed using Language competence tests (LCTs) and their verbal abilities using The Word Guessing Test (WGT) at the beginning of grades 4 and 5 .

The LCT was used to examine the students' semantic awareness and their ability to find and integrate information from the text (Uibu et al., 2010; Uibu \& Tropp, 2013). The WGT measured the children's verbal ability, verbal reasoning and integration of verbal information (Männamaa et al., 2008). In this test the child's task was to infer the name of a concrete or abstract concept by three of its given characteristics.

Teachers' preferences for different teaching practices were measured using Teaching practices questionnaires in grades 3 and 4 (Uibu et al., 2010). The questionnaire covered three areas of teaching practices, focusing on the promotion of the mechanical acquisition of knowledge and skills, developing critical thinking and comprehension and comprising activities that enhance integration and the practical application of knowledge in students. Both variable and person-oriented approaches to the data analysis were employed (Bergman et al., 2003; Cohen et al., 2007).

\section{Major results and discussion}

Proficiency in reading comprehension is considered an important factor for cognitive development and school effectiveness. We examined the development of reading comprehension, verbal abilities and semantic awareness in mother tongue when moving from the first school stage to the second. Using variable and person-oriented approaches in data analysis, differences were found at the group level as well as between subgroups of students with different reading comprehension profiles and subgroups of teachers with different teaching practice profiles.

We found that generally the students who had higher verbal abilities achieved higher results in reading comprehension and word recognition. In addition, students' semantic awareness related more strongly to their verbal ability than their ability to find information in the text, and integrate and interpret information. Previous research has also found that verbal skills are relevant in acquiring vocabulary and differentiating between the meanings of words (Cain \& Oakhill, 2011; Saxton, 2010). Verbal skills and semantic competence, in contrast, are connected with the skill to comprehend text at a lower level, e.g. to recognise information in the text, and at a higher cognitive level, e.g. to analyse and interpret text (Pečjak et al., 2011). 
In line with earlier studies (Logan \& Johnston, 2010; Sinka, 2008) we found that girls exhibited higher results in major fourth grade tasks (verbal ability, reading comprehension and word recognition) and in all fifth grade tasks. To promote boys' reading comprehension it is essential to use texts that are suited to their interest and cognitive level as well as use different reading strategies and practices.

The students' text comprehension and verbal skills may be very different and change in time, i.e. we can see different combinations of text comprehension and verbal skills in fourth as well as fifth grade students. Although several researchers have confirmed the stability of text comprehension (Juel, 1988; Kim et al., 2009; Phillips et al., 2002), the stability does not apply to all students in our sample. Individual differences in stability and change can be found in the students' abilities and also the components of text comprehension and their relationship. Thus, text comprehension is not a one-way process: the results of all students may not improve in time; there are students whose results fall. At the same time, extreme changes in text comprehension during a one-year period are rare.

Students, whose teachers did not use various teaching practices in the lessons, did not achieve good results in text comprehension and verbal abilities tests. When increasing teaching practices that develop students' lower cognitive skills, their text comprehension skill improves. The students, whose teachers' preference of different teaching practices was low, had lower results as a rule. These teachers did not adapt or vary teaching in accordance with the students' cognitive development.

Keywords: reading comprehension, verbal abilities, teaching practices, longitudinal research 